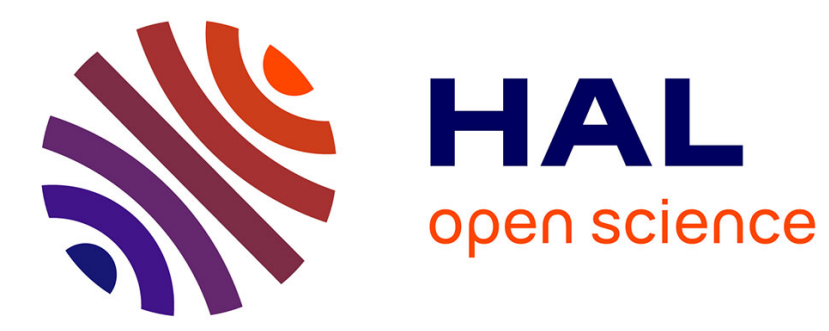

\title{
Length and voicing in Friulian and Milanese
}

Francesc Torres-Tamarit

\section{To cite this version:}

Francesc Torres-Tamarit. Length and voicing in Friulian and Milanese: Or why rule-free derivations are needed. Natural Language and Linguistic Theory, 2015, 33 (4), pp.1351-1386. 10.1007/s11049014-9271-7 . hal-01677835

\section{HAL Id: hal-01677835 \\ https://hal.science/hal-01677835}

Submitted on 8 Jan 2018

HAL is a multi-disciplinary open access archive for the deposit and dissemination of scientific research documents, whether they are published or not. The documents may come from teaching and research institutions in France or abroad, or from public or private research centers.
L'archive ouverte pluridisciplinaire HAL, est destinée au dépôt et à la diffusion de documents scientifiques de niveau recherche, publiés ou non, émanant des établissements d'enseignement et de recherche français ou étrangers, des laboratoires publics ou privés. 


\title{
Length and voicing in Friulian and Milanese \\ Or why rule-free derivations are needed
}

\author{
Francesc Torres-Tamarit
}

Received: date / Accepted: date

\begin{abstract}
This paper claims that phonology should express the relationship between vowel length and obstruent voicing operationally rather than in parallel. The empirical focus in on Friulian and Milanese. The distribution of vowel length in Friulian is predictable from the underlying laryngeal specification of obstruents. Stressed vowels are long before underlyingly voiced word-final obstruents although they devoice. This situation creates opacity. In the light of the interaction between vowel lengthening and final devoicing, this paper argues in favor of Harmonic Serialism, a version of Optimality Theory that combines constraint ranking with serial derivations. I demonstrate that only in Harmonic Serialism does vowel length naturally follow from the independent need to satisfy NoVOICEDCODA and FootBinARITY $\mu$, instead of assuming that vowel lengthening is the consequence of whether or not obstruents project a mora depending on their laryngeal specification. The facts of Milanese are also considered. Milanese patterns as Friulian except that final devoicing is not categorical. I use Serial Variation (Kimper 2011) to solve the problem of opacity and variation in the realization or not of final devoicing. An alternative approach to Milanese that assumes gradual devoicing is also suggested. This analysis combines Harmonic Serialism and turbid output representations (Goldrick 2001, van Oostendorp 2008), and allows us to express formally the difference between Friulian and Milanese in terms of categorical versus gradual devoicing.
\end{abstract}

Keywords Vowel length · Final devoicing · Opacity · Harmonic Serialism · Turbidity Theory

\section{Introduction}

This paper develops a Harmonic Serialism (HS) analysis of an opaque interaction between vowel lengthening and final devoicing in Friulian and Milanese. The distribution of vowel length in these two languages is predictable from the underlying laryngeal specification of immediately

F. Torres-Tamarit

VU University Amsterdam

Faculty of Arts

De Boelelaan 1105

Amsterdam $1081 \mathrm{HV}$

The Netherlands

E-mail: francescjosep.torres@gmail.com 
following word-final obstruents. However, word-final obstruents devoice. I show that the combination of constraint interaction with serial derivations makes vowel lengthening naturally follow from the need to satisfy the independently-motivated markedness constraint against voiced obstruents in coda position, NoVOICEDCODA, and the constraint requiring feet to have two moras, FootBinarity $\mu$. This serial analysis allows for a unitary treatment of devoiced and voiceless obstruents as mora-bearing units, instead of assuming that vowel lengthening is the consequence of whether or not obstruents project a mora depending on their laryngeal specification (Hualde 1990, Iosad 2012). I argue that only a serial account escapes stipulating different moraic representations among devoiced and voiceless obstruents. The analysis is extended to explain the facts of Milanese using Serial Variation (Kimper 2011), where vowel lengthening patterns as in Friulian but in which final devoicing has been said to be optional (Nicoli 1983, Montreuil 1990, Prieto 2000). However, other authors have proposed that final devoicing in Milanese is gradual (Pavia 1928, Sanga 1988). According to the latter interpretation of final devoicing in Milanese, an alternative analysis of Friulian and Milanese combining Harmonic Serialism and Turbidity Theory (Goldrick 2001, van Oostendorp 2008) is suggested that solves two different problems: opacity and variation in the phonetic outcome of final devoicing.

The paper is organized as follows. In $\S 2$, the Friulian data is presented. In $\S 3$, the HS analysis is developed. In $\S 4$, Milanese is analyzed using Serial Variation (Kimper 2011). In $\S 5$, a previous parallel account of the Friulian data is discussed (Iosad 2012). This section also includes an alternative analysis using both Harmonic Serialism and Turbidity Theory. $\S 6$ concludes.

\section{Data}

Friulian exhibits a surface seven-vowel system in stressed position ([i, e, $\varepsilon, \mathrm{a}, \mathrm{\rho}, \mathrm{o}, \mathrm{u}])$, which is reduced to five vowels in unstressed position $([\mathrm{i}, \mathrm{e}, \mathrm{a}, \mathrm{o}, \mathrm{u}]) .{ }^{1}$ It also displays a contrast between stressed short and long vowels in word-final position. Unstressed vowels are always short. The vowel length contrast is synchronically unpredictable before laterals in all dialects and before rhotics in conservative dialects. However, the surface contrast between short and long vowels in stressed position preceding word-final obstruents is predictable from the underlying laryngeal specification of the following obstruent. At the surface level several (near) minimal pairs can be found due to final devoicing (1). ${ }^{2}$

(1) Vowel length contrasts

$\begin{array}{llll}\text { 'la:t } & \text { 'gone-MASC-SG' } & \text { 'lat 'milk' } \\ \text { 'bru:t } & \text { 'broth' } & \text { 'brut } & \text { 'ugly' } \\ \text { 'luss } & \text { 'light' } & \text { 'lus } & \text { 'luxury' } \\ \text { 'fi:s } & \text { 'sons' } & \text { 'fis } & \text { 'fixed, dense' } \\ \text { 'pa:s } & \text { 'peace' } & \text { 'pas } & \text { 'step' } \\ \text { 'pe:s } & \text { 'weight' } & \text { 'pes } & \text { 'fish' }\end{array}$

Only stressed vowels preceding underlyingly voiced word-final obstruents are long. However, voiced obstruents devoice in word-final position. Therefore, final devoicing makes vowel lengthening opaque (2).

\footnotetext{
1 Friulian is a Romance language belonging to the Rhaeto-Romance family spoken in northeastern Italy. The facts described in this paper correspond to Central Friulian, the basis for the standard variety of the language. See Finco (2009) for the most recent description of the basic facts of the phonetics and phonology of Central Friulian.

2 A few words in Central Friulian have stressed long vowels in penultimate position. This is due to historical compensatory lengthening triggered by consonant deletion in clusters: ['ma:ri] 'mother', ['vo:li] 'eye', ['fra:di] 'brother', ['po:re] 'fear', ['je:re] 'ivy'. All the Friulian data come from Vanelli (1979, 1986), Hualde (1990), Prieto (1992, 1994), Repetti (1992, 1994), Baroni and Vanelli (2000), Youngblood (2007), Iosad (2012), Finco (2009). Other sources are cited therein.
} 
(2) Vowel length alternations before underlyingly voiced obstruents

$\begin{array}{llll}\text { 'kru:t } & \text { 'raw-MASC-SG' } & \text { 'krude } & \text { 'raw-FEM-SG' } \\ \text { fi'ni:t } & \text { 'finished-MASC-SG' } & \text { fi'nide } & \text { 'finished-FEM-SG' } \\ \text { 'fu:k } & \text { 'fire' } & \text { fu'gut } & \text { 'fire-DIM' } \\ \text { 'lo:f } & \text { 'wolf-MASC-SG' } & \text { 'love } & \text { 'wolf-FEM-SG' } \\ \text { ris'ti:f } & \text { 'obstinate-MASC-SG' } & \text { ris'tive } & \text { 'obstinate-FEM-SG' } \\ \text { 'na:s } & \text { 'nose' } & \text { na'zut } & \text { 'nose-DIM' }\end{array}$

Before underlyingly voiceless word-final obstruents, stressed vowels remain short (3).

(3) No vowel length before underlyingly voiceless obstruents

$\begin{array}{llll}\text { 'skrit } & \text { 'written-MASC-SG' } & \text { 'skrite } & \text { 'written-FEM-SG' } \\ \text { 'fat } & \text { 'made-MASC-SG' } & \text { 'fate } & \text { 'made-FEM-SG' } \\ \text { 'sek } & \text { 'skinny-MASC-SG' } & \text { 'sece } & \text { 'skinny-FEM-SG' } \\ \text { 'brut } & \text { 'ugly-MASC-SG' } & \text { 'brute } & \text { 'ugly-FEM-SG' } \\ \text { 'mat } & \text { 'crazy-MASC-SG' } & \text { 'mate } & \text { 'crazy-FEM-SG' } \\ \text { 'ros } & \text { 'red-MASC-SG' } & \text { 'rose } & \text { 'red-FEM-SG' }\end{array}$

Another evidence for vowel length being predictable when preceding word-final obstruents comes from loanword adaptation of standard Italian forms (Vanelli 1986). Standard Italian stressed syllables must conform to the binarity requirement of having two moras. This principle is satisfied by means of vowel lengthening or gemination (fato ['fa:to] 'fact' vs. fatto ['fatto] 'done'). When Friulians are exposed to standard Italian forms like impiegato 'employed-MASC' and impiegata 'employed-FEM', they parse the long vowel as present in standard Italian, but they also posit a more abstract representation: the obstruent, although underlyingly voiceless in Italian, is re-interpreted as voiced in Friulian ([impje'ga:t], [impje'gade]). This is not the case when the standard Italian form contains a geminate (affitto 'rental' is parsed with a short vowel and an underlyingly voiceless obstruent in Friulian: [a'fit] 'rent' ( $c f$. [afi'tut] 'rent-DIM')). These data show that vowel length before word-final obstruents is synchronically productive. ${ }^{3}$

The opaque forms in (2) entail a classic analytical problem for parallel Optimality Theory (POT). The structural context that is necessary for vowel lengthening, namely the presence of a following voiced word-final obstruent, is cancelled by final devoicing. A mono-stratal, outputoriented model of grammar like POT is unable to generate the forms in the left column in (2), which become undistinguishable from those in (3) at the surface. ${ }^{4}$

Before sonorants, the distribution of vowel length is a bit more puzzling. Vowels are always short before word-final nasals, as well as before nasal plus stop clusters, or other clusters (4).

(4) No vowel length before nasals and consonantal clusters

$\begin{array}{lll}\text { 'may 'hand' *'ma:y } \\ \text { 'pay 'bread' *'pa:y } \\ \text { 'camp 'field' } & \text { *'ca:mp } \\ \text { 'gust 'taste' } & \text { *'gu:st }\end{array}$

Before laterals, the situation is different: both long and short vowels are possible (5), meaning that before laterals the vowel length contrast is unpredictable, at least synchronically. As will be discussed in $\S 3$, vowel length before laterals and rhotics in conservative dialects (and before laterals and nasals in Milanese) is predictable historically.

\footnotetext{
3 Thanks to the editor of this paper, Michael Kenstowicz, for pointing out this argument to me.

4 POT cannot explain these facts if devoiced and voiceless obstruents have the same representation. See Iosad (2012) for a POT analysis that assumes different representations for devoiced and voiceless obstruents, and the discussion in $\S 5$.
} 
(5) Vowel length constrast before laterals

$\begin{array}{lll}\text { 'val 'valley' } & \text { 'va:l 'it costs' } \\ \text { 'mil 'thousand' 'mi:l 'honey' }\end{array}$

With respect to rhotics, there is interdialectal variation. In conservative dialects, there is also a contrast in vowel length as it occurs before laterals (6).

(6) Vowel length constrast before rhotics

'car 'chariot' 'ca:r 'dear'

However, other non-conservative dialects such as Central Friulian have lost this contrast before rhotics, and vowels always surface as long in this context.

Vowel length before affricates also complicates the whole picture. Although affricates are obstruents, vowels are always short before them, even when affricates are underlyingly voiced (7).

(7) No vowel length before affricates

avan'tats 'advantage' avanta'dza: 'to advantage'

This is true for all dialects. However, in Central Friulian, vowels are long before voiced affricates in one specific morphosyntactic environment, namely in first and third person present indicative forms (8).

(8) Vowel length contrast before affricates in the verbal domain dis'tru:t '(s)he destroys' dis'trudzi 'to destroy'

Vowel length and foot type are intimately related. I assume the moraic trochee to be the default stress pattern in Friulian. As in many other Romance languages, lexical stress in Friulian is subject to a three-syllable window from the right edge of the word. Although stress falling on the fourth syllable from the right is possible, this only happens in encliticized words (puàrtinusal 'bring it to us', comùnichimal 'communicate it to me', Finco 2009). Arguments in favor of considering the moraic trochee as the default stress pattern can be mostly found in the nominal system. Most nominal forms (without derivational affixes) that end in consonant(s) are stress-final, irrespective of whether the last consonant is an obstruent, a sonorant, or a glide. All CVC syllables are therefore heavy (lizêr 'light', palaç 'palace', stazion 'station', ledrôs 'upside down', nevôt 'nephew', Finco 2009). ${ }^{6}$ Those nominal forms that end in a vowel are stress-penultimate (code 'tail', pale 'shovel', mari 'mother', spazi 'space', Finco 2009, Iosad 2012). Antepenultimate-stress forms with a heavy penultimate syllable are not found in the native vocabulary (màrcule 'somersault' but *màcurle, ùltime 'last one-FEM-SG' but * ùtilme, Roseano p.c.). The last syllable in antepenultimate-stress forms is extrametrical. If the penult syllable is heavy, the stress can never fall on the third syllable from the right $(*(\mathrm{CV} . \mathrm{CVC})<\mathrm{CV}>)$. Such footing would correspond to a syllabic trochee, not a moraic trochee. In verbal forms, stress is morphologically-conditioned, and minimal pairs can be found that obscure the basic stress pattern found in nominal forms ( saltin 'let's jump' vs. a saltin 'jump-3-PL', vincin 'let's win' vs. a vincin 'win-3-PL'). Also the plural suffix is invisible for stress assigment (curt 'short' but curtis 'short-PL.', vs. curtis 'knife').

Data from nickname formation also indicates that the basic stress pattern is the moraic trochee. In penultimate-stress bases ending in a vowel, a stress-initial bisyllabic truncated form

\footnotetext{
5 Orthographic 'ç' corresponds to phonetic [ [t]].

6 Words are given in their orthographic form. Stressed syllables appear in boldface if there is no orthographic accent that marks it. The circumflex accent indicates that a stressed vowel is long.
} 
obtains. In stress-final bases ending in a consonant, the truncated form corresponds to the last stressed syllable, a closed syllable (9).

(9) Nickname formation (Roseano p.c.)

$\begin{array}{lllll}\text { Antoni } & \rightarrow \text { Toni } & \text { Macjeu } & \rightarrow & (\mathrm{Cj}) \text { eu } \\ \text { Luigji } & \rightarrow \text { Vigji } & \text { Jusef } & \rightarrow & \text { Sef } \\ \text { Domeni } & \rightarrow \text { Meni } & \text { Francesc } & \rightarrow \text { Ce }(s) c \\ \text { Enrico } & \rightarrow \text { Rico } & \text { Valentin } & \rightarrow \text { Tin }\end{array}$

However, antepenultimate-stress bases such as Annibale, which contain an extrametrical final syllable, are truncated by deleting the pretonic syllable, Nibale (Roseano p.c.). This truncated form can still be considered minimal because the last syllable remains extrametrical, as it was in its base Annibale. In vowel-final stress-final bases such as Indri, the truncation process also deletes the pretonic syllable, yielding Dri (Roseano p.c.), which forms a degenerate, monomoraic foot. This form does not conform to a moraic trochee. However, it must be kept in mind that the unmarked stress pattern in Friulian appears to be just a general tendency in the language: light monosyllables projecting a degenerate foot are permitted as lexical words ( $f$ 'son', $d i$ 'day', Finco 2009, Iosad 2012).

The tendency for building moraic trochees can also be observed in third person singular forms of the present indicative and subjunctive with stressed stems consisting of three or more syllables. These verbal forms end in a vowel and are stress-penultimate irrespective of the original position of stress in Latin, in which stress falls on the third syllable from the right as in modern standard Italian (al/e semene Fr. vs. sémina It. 'seed-3-SG'; al/e masene Fr. vs. màcina It. 'grind-3-SG'; al/e petene Fr. vs. pèttina It. 'comb-3-SG'; al/e ordene Fr. vs. órdina It. 'organize-3-SG'; al/e rodole Fr. vs. ròtola It. 'roll-3-SG', Finco 2009).

The next section shows that the cross-level opaque interaction in Friulian between vowel lengthening before obstruents (a prosodic structure-building operation responsible of inserting a mora) and final devoicing (a segmental structure-changing operation responsible of deleting the feature [voice]) finds a straightforward explanation in HS. The analysis of vowel length before sonorants is also discussed.

\section{Analysis}

\subsection{Harmonic Serialism}

HS is a variant of OT that combines constraint ranking with serial derivations (McCarthy 2010 et seq.). GEN in HS generates those candidates that differ from the input by one single operation. The winning candidate is then fed back to GEN as a new input for another round of evaluation. This loop is repeated until the fully faithful parse of the latest input wins. In short, derivations in HS are always gradual and harmonically-improving, and converge when no further harmonic improvement is achievable.

\subsection{Gradualness and prosody-building operations}

Establishing what counts as a single operation in HS is a question that must be answered on empirical grounds (McCarthy forthcoming).I will show that syllabification can be accomplished simultaneously with another single operation without violating gradualness (as already argued 
for in McCarthy 2007, 2008a, 2009, Pruitt 2010, 2012, Elfner forthcoming). ${ }^{7}$ As opposed to syllabification, stress assignment does count as a single and therefore separate operation (Pruitt 2010, 2012).

Several empirical arguments exist in the literature on HS in favor of considering syllabification a parallel operation and stress assignment a one-step operation. I will report two of them. ${ }^{8}$

In his analysis of syncope in Cairene Arabic, McCarthy (2008a) argues that Gen must supply candidates showing the effects of both syncope and resyllabification. In Cairene Arabic, short

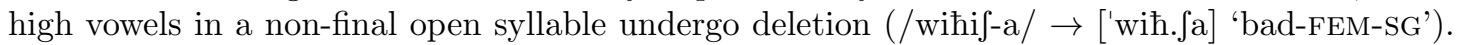
However, syncope does not apply when /i/ is preceded by a consonantal cluster (/hagar kibir/ $\rightarrow$ ['ha.gar.ki.'birr] 'she finished'). If syncope and resyllabification constituted different GEN operations, then an intermediate representation in which the vowel has deleted and the consonant becomes either syllabic or belongs to a nucleusless syllable should be harmonically improving.

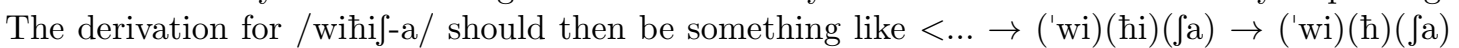
$\rightarrow$ ('wih) $\left(\int a\right)>$, where first syncope applies, and then resyllabification. Whether this derivation is harmonically improving or not depends on the ranking of the markedness constraint favoring syncope, which must dominate the markedness constraint against nucleusless syllables. However, the opposite ranking is needed to block syncope in *[hagarkbirr] (from /hagar kibirr/). If syncope and resyllabification are assumed to be independent processes subject to the gradualness condition on GEN, an undesirable ranking paradox obtains. However, if syncope and resyllabification are collapsed into a single GEN operation, then the ranking in which the syncope-favoring constraint dominates the constraint against degenerate syllables still blocks syncope in /hagar kibir/ as a consequence of the independently needed constraint *Complex. This is so because the amount of available information at the derivational step in which syncope has the chance to apply is large enough to look ahead to the consequences of resyllabification, which include candidates that fatally violate *COMPLEx. The intermediate representations *('ha)(gark)('birr) or *('ha) (gar)('kbirr) are ruled out, so convergence is reached before there is a chance to apply syncope. This is not the case for ('wiћ)( (Ja), which does not violate *Complex.

In Elfner (forthcoming), it is argued that stress assignment counts as a single operation in the light of stress-epenthesis interactions, which can be transparent or opaque. For opaque stressepenthesis interactions, foot building must necessarily be accomplished separately from epenthesis. In Dakota, for instance, epenthetic vowels are invisible for stress assignment, meaning that the regular stress pattern, which falls on the second syllable of the word, is not surface-true in

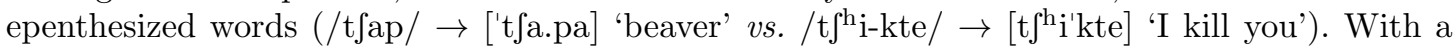
ranking in which the constraint requiring words to have stress dominates the constraint prohibiting codas, stress takes priority over vowel epenthesis. This result can only be accomplished if GEN does not supply candidates with both stress and epenthesis at the same derivational step.

I will show that the Friulian opaque interaction between vowel lengthening and final devoicing also gives evidence in favor of considering stress assignment a one-step operation that cannot co-occur with final devoicing, but the latter does co-occur with coda syllabification.

\subsection{Moraic surface representations}

I propose to represent both devoiced and voiceless obstruents in coda position as mora-bearing units (10). Therefore, I interpret vowel lengthening as the result of a mora-sharing configuration,

\footnotetext{
7 The other approach to syllabification in HS is based on an operation-based definition of gradualness, by which all prosody-building operations, including syllabification, count as one-step operations (Jesney 2011, Elfner 2009, Elsman forthcoming, Pater 2012, Pater forthcoming).

8 There are some inconsistencies in the literature on what it means to make one change at a time in HS. See McCarthy (forthcoming) for a first attempt to achieve some consensus on this issue.
} 
where the dependent mora of a monosyllabic, bimoraic foot, branches, that is, dominates both the syllable head, always a vowel, and the coda. A subscript $\mathrm{D}$ stands for a devoiced obstruent and $\mathrm{VL}_{\mathrm{L}}$ for a voiceless obstruent.

(10) Moraic surface representations

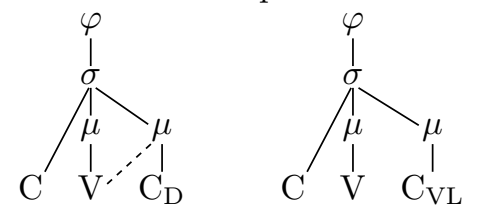

With respect to laryngeal specifications, I assume that [voice] is a privative feature (Lombardi 1999). The process of final devoicing consists of deleting this feature, thus assigning to a devoiced obstruent the representation of a voiceless obstruent, both lacking the feature [voice]. I therefore assume complete neutralization in coda position for Friulian. In $\S 5$, I will return to this issue. For now, it is worth noting that the proposed moraic surface representations are neutral with respect to an alternative claim considering final devoicing an incomplete neutralization process (Baroni and Vanelli 2000, Iosad 2012). However, I will argue that, irrespective of whether devoiced and voiceless obstruents show a different featural composition, their ability to license a mora should be kept the same. If not, opacity is resolved by assuming different representations at two different levels: the subsegmental level and the moraic tier. If this is assumed, then opacity is resolved by a circular argument that hinges on a previous assumption: due to the fact that obstruents are not completely neutralized (i.e., they are characterized by a different featural configuration), their ability to license a mora is not the same. By contrast, I propose that, in the absence of independent motivation, the assignment of moraic structure to melodic units is independent of whether word-final obstruents undergo complete laryngeal neutralization, partial devoicing, or whether the contrast is presumably maintained by other cues such as closure duration or weaker bursts (Baroni and Vanelli 2000).

\subsection{Constraints and operations}

I consider stress assignment (i.e., metrical foot building) an unfaithful input-output mapping triggered by the satisfaction of the markedness constraint ProsodicWordHeAd (11), which dominates the faithfulness constraint DepProminence (12). Due to the fact that building a metrical foot ties with one violation of a faithfulness constraint (DEPPROMINENCE), stress assignment cannot co-occur with other operations such as vowel lengthening or final devoicing.

(11) ProsodicWordhead (PWdHd)

Assign one violation mark for every prosodic word without a head metrical foot. (Elfner forthcoming)

(12) DepProminence (DepProm)

Assign one violation mark for every metrical prominence in the output that is not present in the input. (Elfner forthcoming)

The stress pattern in Friulian corresponds to a right-aligned moraic trochee, as proposed in $\S 2$. Coda consonants are thus weight-contributing, which results from ranking WEIGHTBYPosition (13) above ${ }^{*} \mathrm{C} \mu(14)$. 
(13) WeightbyPosition (WBP)

Assign one violation mark for every coda consonant that does not project a mora (Hayes 1989).

(14) ${ }^{*} \mathrm{C} \mu$

Assign one violation mark for every head of a mora that is a consonant. (Broselow et al. 1997)

Weight-sensitivity in stress assignment is the result of satisfying FоOTBINARITY $\mu$, formulated in (15).

\section{(15) FootBinarity $\mu($ FtBin $\mu)$}

Assign one violation mark for every foot that does not contain at least two moras. (McCarthy and Prince 1996, Prince 1983).

Syllable formation operations are cost-free. ${ }^{9}$ However, GeN can leave some segments unparsed. Underparsing can be optimal if it contributes to better performance on some top-ranked markedness constraint such as NOVOICEDCODA. The markedness constraint violated when segments are left unparsed is ParseSEgment, defined in (16).

\section{(16) ParseSegment (PrsSeg)}

Assign one violation mark for every segment that is not associated with a syllable or a higher-level prosodic constituent. (Elfner forthcoming)

The feature [voice] is only licensed by association with an onset. Laryngeal neutralization in coda position can be interpreted as the result of ranking the contextual markedness constraint NoVoicedCoda (17) above the anti-deletion faithfulness constraint Max([voice]) (18), and the latter above the context-free markedness constraint *[voice] (19).

(17) NoVoicedCoda (NoVcdC)

Assign one violation mark for every voiced obstruent in coda position. (McCarthy 2008b)

(18) $\operatorname{Max}([\operatorname{voice}])(\operatorname{Max}([\mathrm{vc}]))$

Assign one violation mark for every feature [voice] in the input that has no correspondent in the output. (Lombardi 1999, 2001)

(19) $*[\operatorname{voice}](*[\mathrm{vc}])$

Assign one violation mark for every feature [voice] in the output. (Lombardi 1999, 2001)

Finally, I propose that vowel lengthening is a phonological process that violates two different faithfulness constraints depending on the previous input, namely DeP $\mu$ and DepLink. I follow Bermúdez-Otero (2001) in defining the former constraint (20).

(20) $\operatorname{DEP} \mu$

Assign one violation mark for every mora in the output linked to a non-positionally $\mu$-licensed segment that has no correspondent in the input. (Bermúdez-Otero 2001)

This revised formulation of $\operatorname{DEP} \mu$ avoids penalizing weight by position and coda adjunction, which, as opposed to vowel lengthening, are basic syllabification operations. Bermúdez-Otero (2001) proposes the condition in (21) to establish when a segment is positionally $\mu$-licensed.

\footnotetext{
9 Syllable formation operations are traditionally referred to as core syllabification (building a CV syllable), coda adjunction $((\mathrm{CV}) \mathrm{C} \rightarrow(\mathrm{CVC}))$ and resyllabification. In my proposal syllabification applies in parallel, so these operations can be freely collapsed.
} 
(21) Positional $\mu$-licensing

A non-syllabic segment $\alpha$ is positionally $\mu$-licensed by a mora $\mu$ if, and only if,

(a) $\alpha$ does not have an input correspondent linked to a $\mu$, and

(b) $\alpha$ is immediately dominated only by $\mu . "$ (Bermúdez-Otero 2001:7). ${ }^{10}$

In the case of vowel lengthening, understood as mora insertion, a segment $\alpha$, a vowel, is immediately dominated by two moras, thus not complying with condition (b) in (21), and therefore violates $\operatorname{DEP} \mu(22)$.

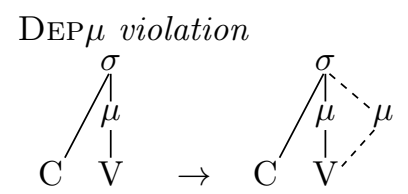

Apart from mora insertion, vowel lengthening can also be the result of inserting an association line between the vocalic root node and a mora that already heads a consonant in the preceding input. In this case, the violated faithfulness constraint is not DEP $\mu$, but DEPLINK (23).

\section{(23) DepLink (DepLK)}

Let $s_{1}$ be a segment in the input in correspondence with $S_{2}$ in the output; and let $\mu_{1}$ be a mora in the input in correspondence with $\mu_{2}$ in the output. Assign one violation mark for every $\mu_{2}$-to- $S_{2}$ link in the output that has no $\mu_{1}$-to- $s_{1}$ link correspondent in the input (Morén 1999).

It is clear from the definition in (23) that the mapping in (22) does not violate DEPLINK. In (22), DepLink is vacuously satisfied due to the absence of an input correspondent of the second mora in the output. The mapping in (24) does violate DepLink.

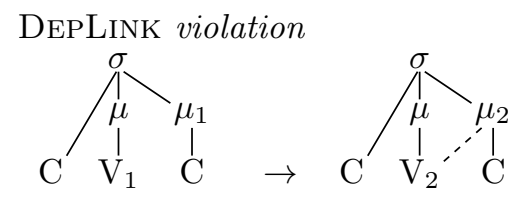

The difference between DEP $\mu$ and DepLink will be crucial for deriving the vowel length alternation in Friulian.

To recapitulate, table 1 shows the crucial operations that GEN is able to perform at once. However, none of the operations in the left column in (1) can be performed simultaneously because this would incur a violation of two faithfulness constraints at once, thus not complying with gradualness.

Table 1 Gen operations

\begin{tabular}{llll}
\hline operations & & & constraints violated \\
\hline foot building & $(+$ & syllabification $)$ & DEPPROM \\
devoicing & $(+$ & syllabification $)$ & MAx $([\mathrm{vc}])$ \\
lengthening & $(+$ & syllabification $)$ & DEP $\mu$ or DEPLK \\
\hline
\end{tabular}

\footnotetext{
10 See also Campos-Astorkiza (2004) for a formulation of DEP $\mu$ in similar terms.
} 


\subsection{Derivations}

\subsubsection{Opaque vowel length before underlyingly voiced obstruents}

Consider an input containing an underlyingly voiced obstruent in word-final position. Different operations are available at the first step of the derivation. One possibility is to project a foot and parse the whole string of segments, as candidate (c) in (25). However, this candidate fatally violates top-ranked NoVoICEDCODA. This constraint can be satisfied by means of devoicing, as candidate (b) shows. Nevertheless, due to the fact that devoicing cannot co-occur with foot building, candidate (b) is ruled out by PROSODICWORDHEAD. It is crucial that the transparent candidate showing both metrical foot building and final devoicing cannot be generated at this step due to faithfulness-based gradualness. The winning candidate, (a), satisfies NoVoICEDCodA by leaving the word-final voiced obstruent unparsed, and PROsoDICWORDHEAD by projecting a degenerate monomoraic metrical foot. Candidate (a) is the most harmonic candidate although it violates relatively low-ranked FootBinarity $\mu$ and PARseSEgment. The tableau (25) shows that both NoVoicedCoda and ProsodicWordHead dominate FootBinarity $\mu$ and ParsESEGMENT. ${ }^{11}$

(25) Step 1

\begin{tabular}{|c|c|c|c|c|}
\hline /lad/ & NoVCDC & PWDHD & FTBIN $\mu$ & PrSSEG \\
\hline a. ${ }_{1} \frac{\rho}{d}$ & & $\begin{array}{l}1 \\
\vdots \\
\vdots \\
1 \\
1 \\
1 \\
1 \\
1\end{array}$ & * & * \\
\hline b. $\left.\quad \int_{\mathrm{a}}\right|_{\mathrm{t}}$ & & ${ }^{*} \mathrm{~W}$ & $\mathrm{~L}$ & $\mathrm{~L}$ \\
\hline c. $\quad \mathrm{l}_{\mathrm{a}}$ & ${ }^{*} \mathrm{~W}$ & & $\mathrm{~L}$ & $\mathrm{~L}$ \\
\hline
\end{tabular}

At the second step of the derivation, vowel lengthening takes place, which is the most optimal available operation that satisfies both FootBinariTy $\mu$ and ${ }^{*} \mathrm{C} \mu$. The latter is fatally violated by candidate (b) in (26), which shows coda adjunction and simultaneous final devoicing. Candidate (c), the fully faithful parse of the input, is ruled out because it violates FoотBinARITY $\mu$. The last candidate, (d), satisfies FoOTBINARITY $\mu$ by deleting the foot, but this option is not harmonicallyimproving because it violates top-ranked ProsodicWordHead. Both ParseSegment and DEP $\mu$ are violated by the winning candidate, (a). Notice that DEPLink, ranked at the top

11 Throughout this paper tableaux are presented in comparative format (Prince 2002), and also include traditional violation marks. A capital $\mathrm{W}$ is entered into the cell of a particular loser row if the winner is favored over that loser by the constraint in that column. A capital L is inserted in the opposite situation, that is, if that loser is favored over the winner. Nothing is inserted if neither the winner nor a particular loser are favored by a specific constraint. Every L must be dominated by at least one W in comparative tableaux, meaning that every loser-favoring constraint is dominated by at least one winner-favoring constraint. This type of tableau is especially useful in constructing and presenting ranking arguments. Dashed and solid lines respect the whole ranking of the grammar. Only those candidates that illustrate ranking arguments will be included in the tableaux. 
of the hierarchy, is not violated by the winning candidate, which only violates low-ranked DEP $\mu$ due to the absence of the second mora in the input. The tableau (26) shows that ${ }^{*} \mathrm{C} \mu$ dominates both PARseSEgment and DeP $\mu$, and that both FootBinarity $\mu$ and ProsodicWordHeAd dominate $\operatorname{DEP} \mu$.

(26) Step 2

\begin{tabular}{|c|c|c|c|c|c|c|c|}
\hline$\rho_{\mathrm{l}}{ }_{\mathrm{a}}^{\varphi} \mathrm{d}$ & NoVCDC & $\begin{array}{l}\text { : } \\
\vdots \\
1 \\
\text { PWDHD }\end{array}$ & $\begin{array}{ll} \\
1 \\
1 \\
\text { DEPLK }\end{array}$ & FтBIN $\mu$ & ${ }^{*} \mathrm{C} \mu$ & PRSSEG & DEP $\mu$ \\
\hline a. $\left.{ }_{1}^{\rho}\right|_{\mathrm{a}}$ & & $\begin{array}{c}\vdots \\
\vdots \\
\vdots \\
\vdots \\
\vdots \\
\vdots\end{array}$ & $\begin{array}{c}1 \\
\vdots \\
1 \\
1 \\
1\end{array}$ & & & $*$ & $\begin{array}{c}1 \\
1 \\
1 \\
1 \\
1 \\
1 \\
1 \\
1\end{array}$ \\
\hline 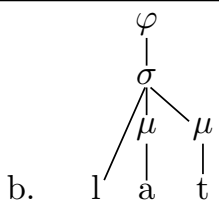 & & $\begin{array}{c}\vdots \\
\vdots \\
\vdots \\
\vdots \\
\vdots \\
\vdots\end{array}$ & $\begin{array}{c}1 \\
\vdots \\
\vdots \\
1 \\
1\end{array}$ & & ${ }^{*} \mathrm{~W}$ & $\mathrm{~L}$ & $\begin{array}{c}1 \\
1 \\
1 \\
1 \\
1 \\
1 \\
1 \\
1\end{array}$ \\
\hline 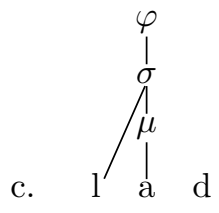 & & $\begin{array}{c}: \\
\vdots \\
\vdots \\
\vdots \\
\vdots \\
\vdots \\
\vdots\end{array}$ & $\begin{array}{l}1 \\
1 \\
1 \\
1 \\
1\end{array}$ & ${ }^{*} \mathrm{~W}$ & & $*$ & $\begin{array}{l}1 \\
1 \\
1 \\
1 \\
1 \\
1 \\
1 \\
1\end{array}$ \\
\hline d. $\quad \int_{\mathrm{a}}{ }_{\mathrm{a}} \mathrm{d}$ & & *W & $\begin{array}{c}1 \\
\vdots \\
\vdots \\
1\end{array}$ & & & $*$ & $\begin{array}{l}\text { I } \\
\text { I }\end{array}$ \\
\hline
\end{tabular}

The unparsed voiced obstruent is adjoined to the already existing syllable as a devoiced obstruent at the third step of the derivation (27). Coda adjunction is triggered by the satisfaction of PARseSegment, which dominates Max([voice]). Recall that parsing a segment and applying final devoicing can be accomplished at once because syllabification is not subject to gradualness. Only applying coda adjunction, as candidate (c) shows, is not optimal because NoVoICEDCODA dominates $\operatorname{MAx}([$ voice] $)$. 
(27) Step 3

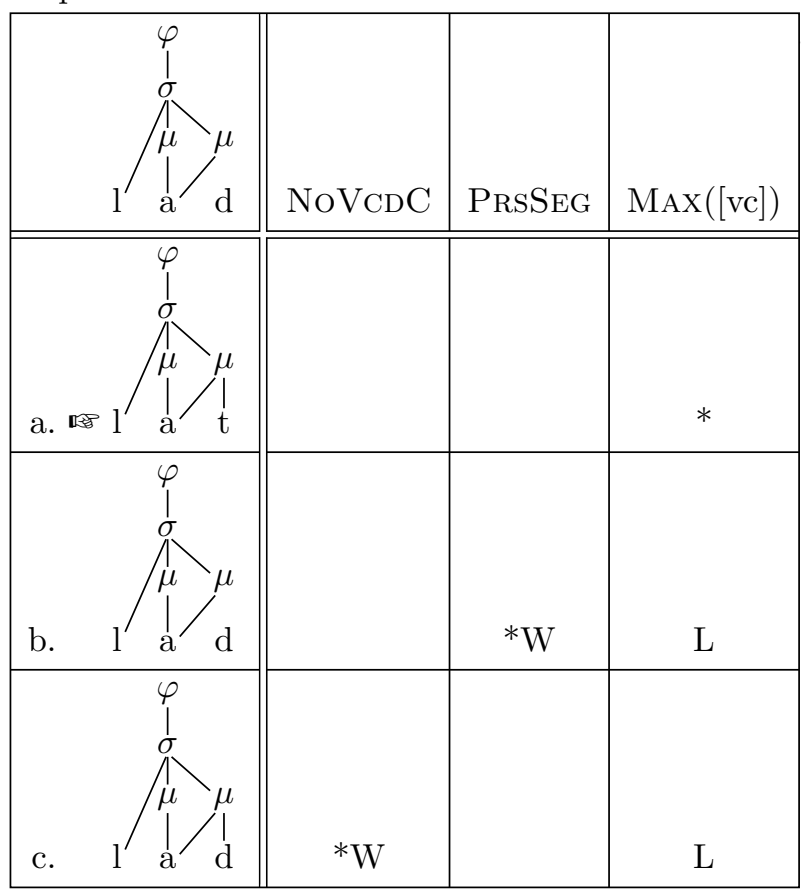

The derivation converges at the next step because further harmonic improvement is not achievable (28). Candidate (c) inserts the feature [voice], thus violating NoVorcedCodA, and candidate (b) deletes the association line connecting the vowel with the second mora, thus violating ${ }^{*} \mathrm{C} \mu$. Candidate (c) additionally violates $\operatorname{DeP}([$ voice $])$ and candidate (b), MaxLink, but these constraints have not been included in the tableaux because their ranking is unknown and the previously needed constraints NoVoICEDCODA and ${ }^{*} \mathrm{C} \mu$ have the same effect. ${ }^{12}$

\footnotetext{
12 A candidate with word-adjunction and no devoicing ( $\left.\left.\left[\left[\mathrm{la}_{\mathrm{a}}\right]_{\sigma}\right]_{\varphi} \mathrm{d}\right]_{\omega}\right)$ is not included in the tableau in (27) for ease of exposition at this point. However, the candidate with word-adjunction, although it satisfies NoVoicedCoda, violates Exhaustivity, which is ranked above Max([voice]). The ranking Exhaustivity 》 $\operatorname{MAx}([\operatorname{voice}])$ favors the candidate with syllable-adjunction and devoicing.
} 
(28) Step 4: convergence

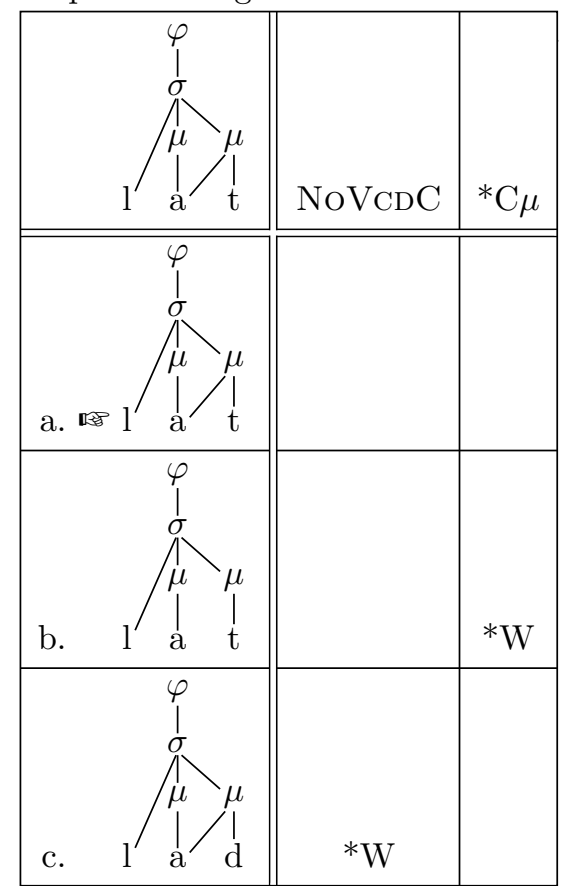

\subsubsection{No vowel length before underlyingly voiceless obstruents}

When the word-final obstruent is voiceless, it can be syllabified at the first step of the derivation. Top-ranked WeightByPosition, NoVoicedCoda, ProsodicWordHead, and relatively topranked FootBinarity $\mu$, can be satisfied at once (29).

(29) Step 1

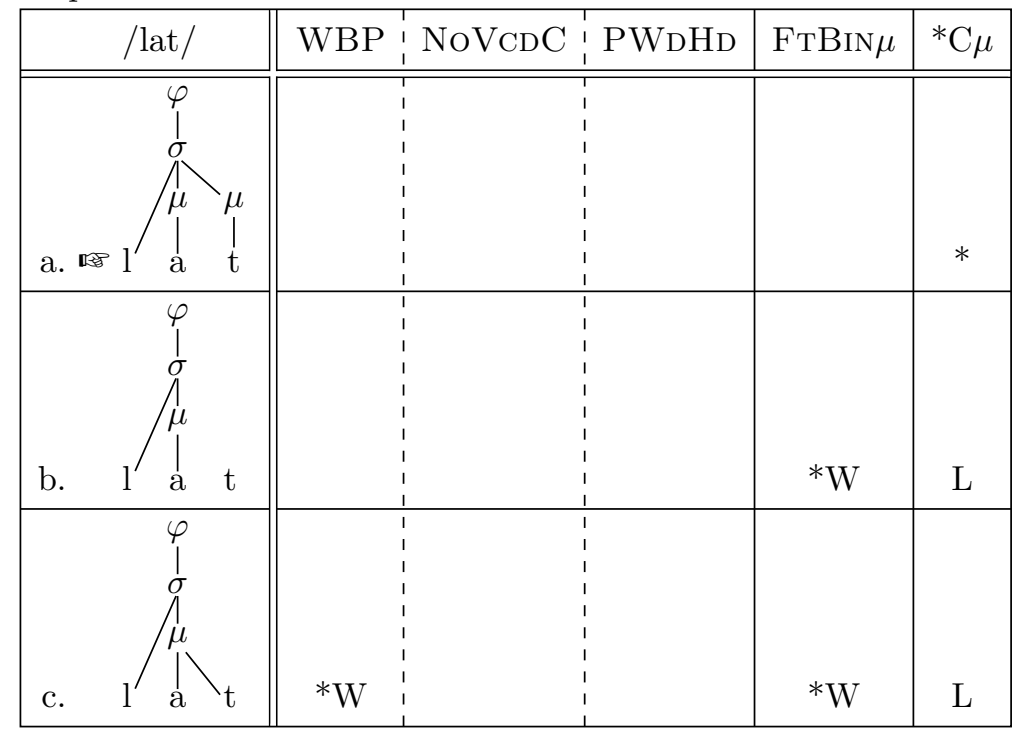

The derivation converges at the next step of the derivation (30). Candidate (b), with vowel lengthening, is discarded because it violates undominated DePLink, which dominates ${ }^{*} \mathrm{C} \mu$, the 
only constraint that the winning candidate violates. As previously noted, DEPLINK is violated when a mora and a segment are present in the input and a new autosegmental relation between them is present in the output. This is why vowel lengthening is allowed before coda adjunction (tableau 26), but blocked after coda adjunction (tableau 30).

(30) Step 2: convergence

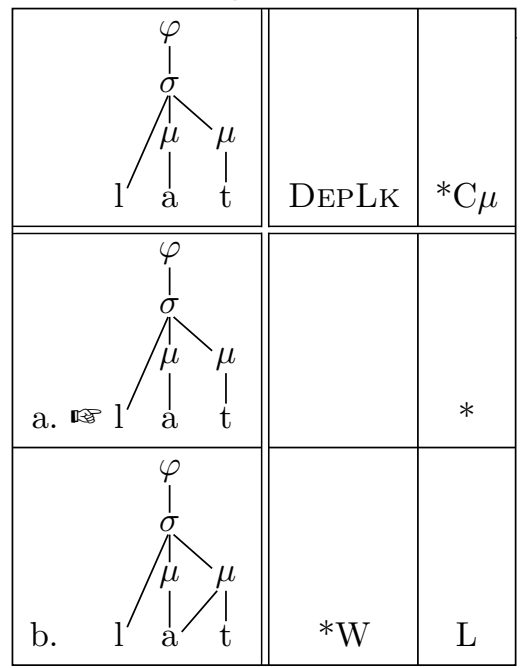

\subsubsection{In favor of uniform moraification in codas}

The analysis presented so far places the burden of explanation on the organization of the foot and the need to satisfy NoVoicedCoda and FootBinarity $\mu .{ }^{13}$ However, most previous analyses placed the burden of explanation on the weight structure of the syllable.

Hualde (1990), in his rule-based analysis of Friulian, assumes that only voiced obstruents license a mora, but voiceless obstruents do not. In the latter case, he assumes degenerate feet for words ending in an underlyingly voiceless obstruent. For words containing an underlyingly voiced obstruent, devoicing enforces deletion of the link between the obstruent and its mora. After final devoicing, the floating mora previously projected by the voiced obstruent must re-link to the vowel (31).

(31) Hualde's (1990) rule-based analysis

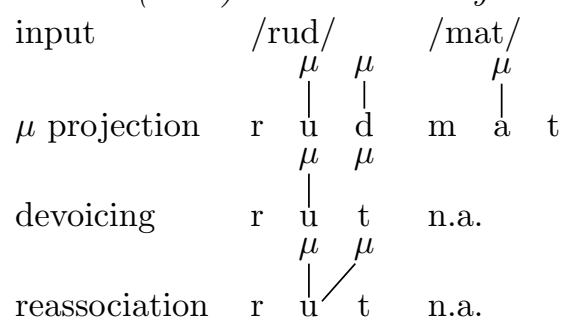

Later on, Iosad (2012), which will be discussed in more detail in $\S 5$, proposes the opposite of Hualde (1990) in his POT analysis. Only voiceless obstruents project a mora according to him, and for this reason the absence of vowel lengthening in this context is predicted. On the other hand, devoiced obstruents do not license a mora and lengthening is required to satisfy

\footnotetext{
13 FootBinarity $\mu$ also triggers lengthening in Iosad (2012), but not NoVoicedCoda.
} 
FootBinarity $\mu$. The idea that devoiced obstruents cannot project a mora is not stipulated as in Hualde (1990), but follows from the fact that devoiced obstruents are given a different representation than that for voiceless obstruents. This difference is what ultimately justifies a difference in their ability to license a mora. The problem with such an account is that no independent argument in favor of considering either voiced or voiceless obstruents to be mora licensers exists, and this explains the divergence found between Hualde (1990) and Iosad (2012).

The novelty of the analysis proposed in this paper is that, in the absence of counterarguments, all consonants in the coda are moraic, as all word-final consonants attract stress ( 22$)$. Furthermore, I will argue in $\S 5$ that a non-categorical analysis of final devoicing as the one presented in Iosad (2012) is not clearly supported by the (scarce) phonetic data available in the literature (Baroni and Vanelli 2000).

\subsubsection{Underparsing as a repair strategy for NoVoICEDCODA}

The analysis presented so far assumes that underparsing is an available strategy to satisfy NoVolcedCodA, at least temporary underparsing (before coda adjunction plus devoicing in Friulian and before parsing a voiced obstruent as a degenerate syllable not subject to final devoicing in Milanese, as will be seen later). Underparsing as a strategy to repair a NoVoICEDCODA violation is not reported in Steriade (2001), who claims that voiced obstruent codas are exclusively satisfied by means of devoicing cross-linguistically. However, some very interesting data has been recently discussed that compromise this view. In José and Auger (2004), voiced obstruent codas following nasal vowels are not devoiced but nasalized (/gãb/ $\rightarrow$ [gãm] 'leg' ( $c f$. [gãbe] 'kicking action'); /repõd/ $\rightarrow$ [repõn] 'to answer' ( $c f$. [repõdy] 'answered')). Epenthesis has also been claimed to be an available repair strategy to satisfy NoVorcedCoDA in some Flemish dialects according to van Oostendorp (200X), where forms can end in a voiceless stop ([nənbə:t] 'a beard'), but forms ending in an underlyingly voiced stop are always followed by a schwa ([əmrebə] 'a rib'). More interestingly, Dow (2013) reports data on Berbice Dutch Creole from Kouwenberg (1994), where deletion, and vowel epenthesis, are strategies to avoid voiced obstruent codas. In Berbice Dutch Creole, root-final vowels are subject to an optional process of syncope ([pama] $[$ pam] 'to finish'; [pleks] [plek] 'place'). However, syncope is blocked when the result would yield a word-final voiced obstruent (/saba/ $\rightarrow$ [sa.ba ${ }^{*}[\mathrm{sab}]$ 'cross'). When roots contain a nasal plus obstruent cluster before the final vowel, as in [kante] 'not be able', vowel syncope can perfectly apply, yielding [kant]. However, when the stop is voiced, as in [findi] 'to find', optional vowel syncope does not apply unless the voiced stop also deletes, yielding [fin]. Vowel syncope without stop deletion would yield an offending voiced coda (*find). However, deletion of an underlyingly voiceless stop is blocked because, whenever NoVoicedCODA is satisfied, two deletions are unmotivated $(*[\mathrm{kan}])$. In Berbice Dutch Creole, deletion of a voiced obstruent repairs a violation of NoVoicedCoda in nasal plus stop clusters. But also vowel epenthesis is a repair strategy, because, in keeping with Richness of the Base, an underlying form /flig/ 'fly' or /find/ could also be mapped into [fli.gi] and [fin.di], respectively, the latter form alternating with [fin]. This language thus gives additional support to the analysis of Friulian presented in this paper, where underparsing is temporal. ${ }^{14}$ The crucial difference between Friulian and Berbice Dutch Creole is that the high-ranking of PARSESEGMENT in Friulian makes underparsing a temporary solution through the derivation, whereas in Berbice Dutch Creole underparsing persists to the end of the phonological derivation, meaning that the underparsed segment is not pronounced. What these data suggest is that NoVoICEDCODA can be satisfied by means other than devoicing, namely deletion and vowel epenthesis, as opposed to what was previously thought.

\footnotetext{
14 I assume that underparsed segments are not realized by the phonetics at the end of the derivation.
} 


\subsubsection{Vowel length before sonorants}

Developing a unitary account of vowel length before sonorants presents several challenges. As opposed to expectations, not all sonorants pattern with voiceless obstruents although they lack the feature [voice], and affricates do not pattern with obstruents in general.

Nasals Vowels are always short before nasals. This is not surprising since nasals are unspecified for the feature [voice], and therefore pattern with voiceless obstruents. Nasals can be syllabified in coda position at the first step of the derivation without violating NoVoICEdCodA. ${ }^{15}$ The derivation given for vowels preceding voiceless obstruents in (29) and (30) is identical to that for vowels preceding nasals.

Laterals The distribution of vowel length before laterals is not uniform. Due to the fact that vowel length is contrastive before laterals, some extra information must be encoded in the lexicon. I propose that vowel lengthening before certain laterals also surfaces as a way to satisfy FoOTBINARITY $\mu$, as is the case for vowel lengthening before underlyingly voiced obstruents. However, the reason why laterals are left temporarily unparsed has nothing to do with NoVoICEDCoDA. Those laterals triggering vowel lengthening are specified in the lexicon as extrametrical. On the other hand, vowels surface as short before non-extrametrical laterals. In the latter case, laterals pattern with nasals and voiceless obstruents as expected, in the sense that they can be parsed in syllable coda position without violating NoVOICEDCODA and therefore block vowel lengthening. A faithfulness constraint FAITHFulness(extrametricality), defined in (32), ranked above FooTBinarity $\mu$ and PARseSegment, is responsible for leaving the lexically extrametrical lateral unparsed and building a monomoraic foot at the first step of the derivation (33).

(32) FAithfulness(extrametricality) (FAith(extramet)) (Inkelas et al. 1997)

Assign one violation mark for every lexically extrametrical consonant that is parsed below the foot.

(33) Step 1

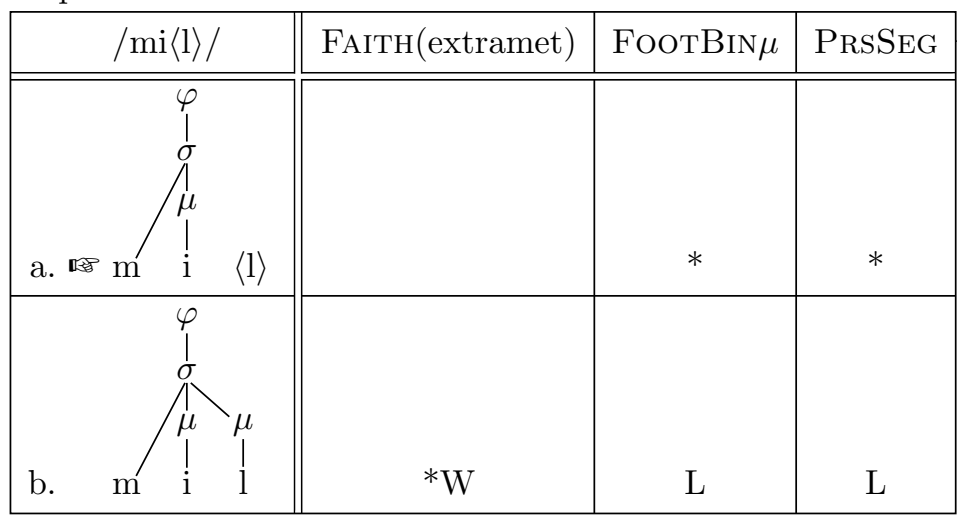

15 An anonymous reviewer points out that ROTB does not preclude an input where nasals, and other sonorants, are specified for the feature [voice]. By allowing sonorants specified for [voice] in the output, the constraint NoVoICEDCODAs should be defined to target only obstruent codas. However, I assume that sonorants lack a privative [voice] feature in the output because in the unmarked situation sonorants do not contrast for voice, and this is precisely the case in Friulian. Following ROTB, an input with a sonorant specified for [voice] should map into a representation where the [voice] feature is absent. This scenario could easily be derived by ranking a feature co-occurrence constraint $*\{[$ voice][son] $\}$, prohibiting sonorants specified for the [voice] feature, above $\operatorname{MAx}($ voice)/son, against deletion of the [voice] feature in sonorants. In languages where sonorants contrast for [voice], the opposite ranking would obtain. 
At the next step of the derivation, FootBinarity $\mu$ is satisfied by means of vowel lengthening (35). The winning candidate, (a), violates ParseSegment DeP $\mu$ and Exhaustivity, defined in (34), which prohibits skipping of prosodic constituents (Selkirk 1995).

(34) Exhaustivity (Exhaust)

Assign one violation mark for every constituent $\mathrm{C}_{i}$ that immediately dominates a constituent $\mathrm{C}_{k}, \mathrm{k}<\mathrm{i}-1$. (Selkirk 1995)

(35) Step 2

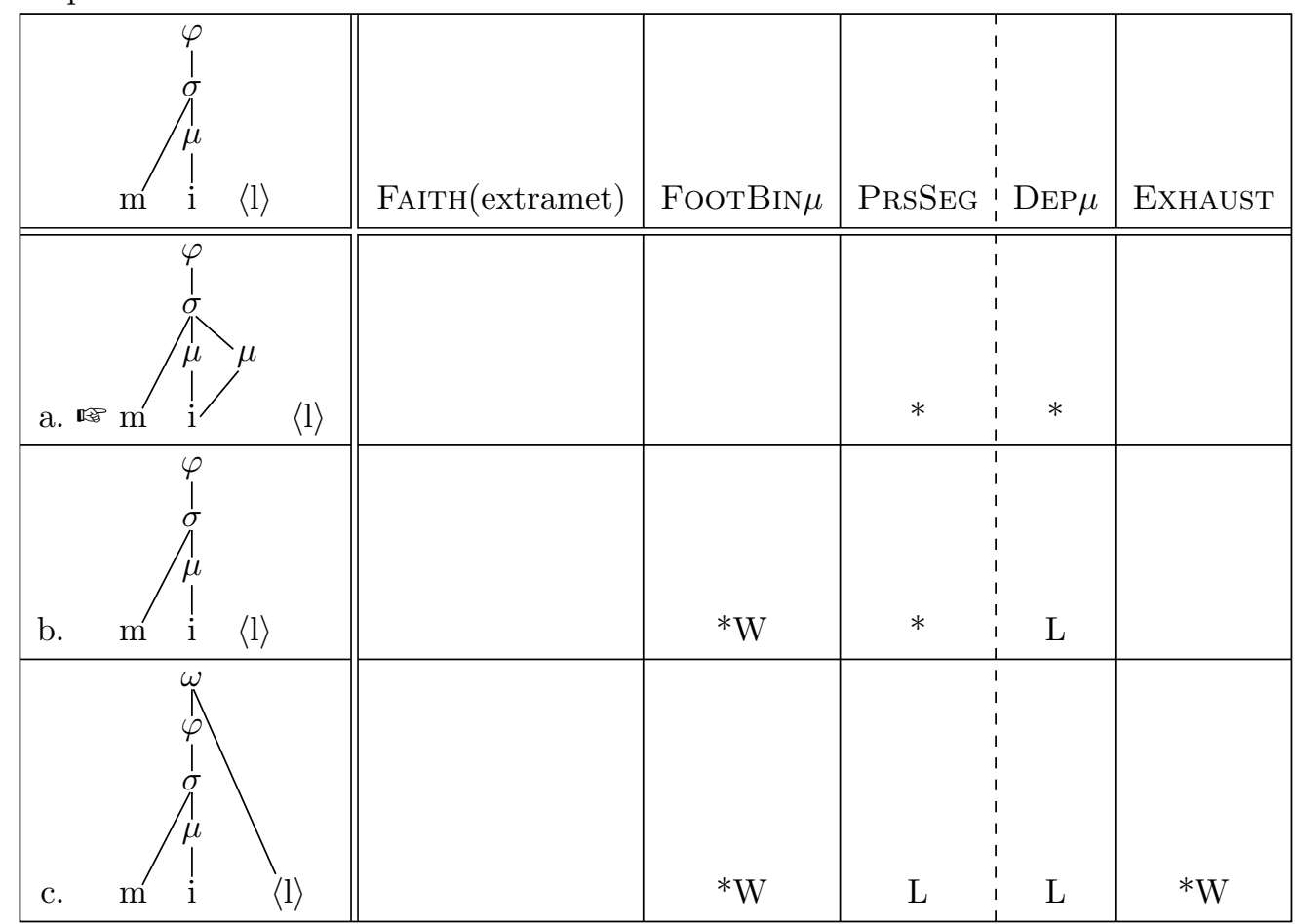

It is at the third step of the derivation when PARSESEGMent can be satisfied by means of adjunction of the underlyingly extrametrical lateral to the prosodic word node. ${ }^{16}$

\footnotetext{
16 Notice that adjunction is a one-step operation as opposed to parsing a segment into a syllable. ExHAUSTIVITY is always responsible for preferring parsing segments into syllables unless other markedness constraints prohibit that (NoVoicedCoda in this analysis).
} 
(36) Step 3

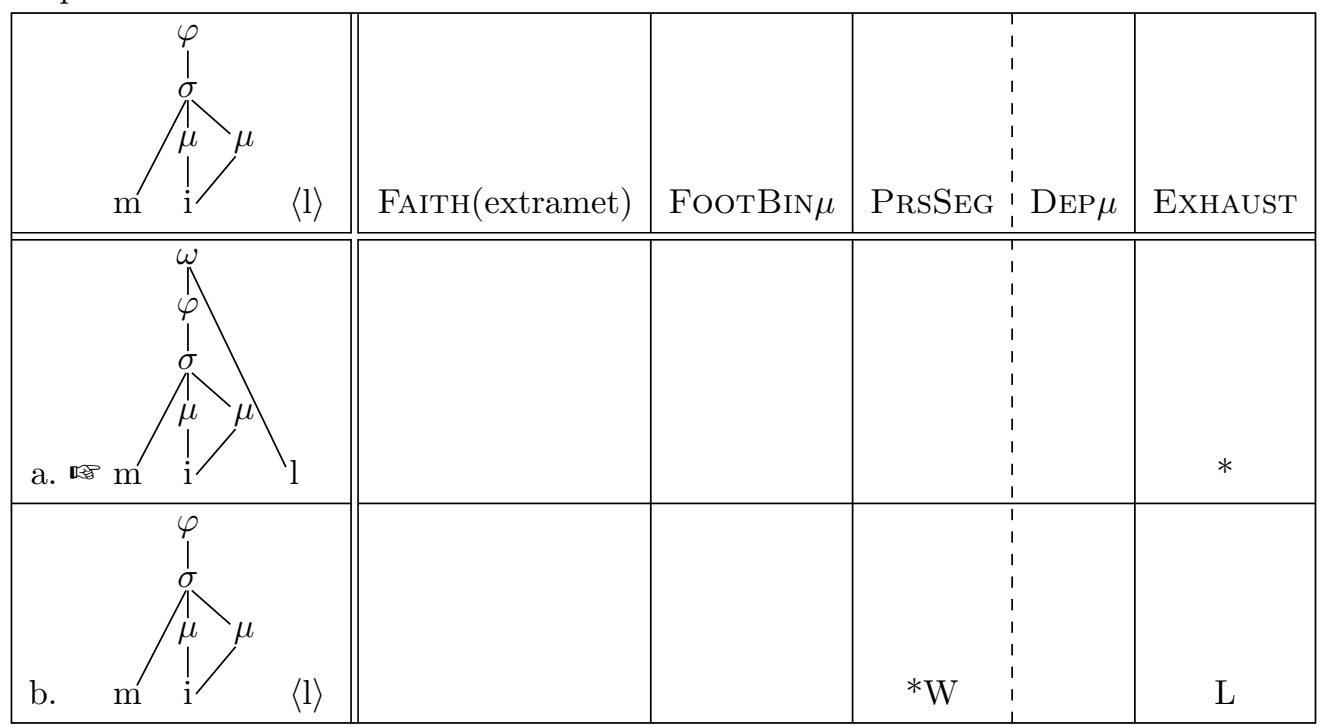

Rhotics The same analysis given for laterals explains vowel lengthening before rhotics in conservative dialects. Extrametrical rhotics trigger vowel lengthening, while non-extrametrical rhotics are incorporated as codas at the first step of the derivation blocking vowel lengthening.

Vowel length before sonorants as a historical residue The Friulian data seem to go against a sonority-based approach to weight. It is a well-known fact that more sonorous segments are more suitable to license weight than less sonorous segments (Zec 1995). However, although laterals are more sonorous than nasals, some laterals, those following long vowels, are not moraic under the analysis presented here. On the contrary, all nasals contribute to weight and head their own mora although they are the less sonorous sonorants. However, I will argue that Friulian does not represent a case against a sonority-based approach to syllable weight.

Postulating underlying extrametricality makes sense from a diachronic perspective. Short vowels are found before laterals that where geminates in Latin (MILLE $\rightarrow$ ['mil] 'thousand', PELLE $\rightarrow$ ['pjel] 'skin'), and long vowels are found before laterals that where singletons in Latin (MELE $\rightarrow$ ['mill] 'honey'). I propose that after historical word-final vowel loss, speakers re-interpreted singleton laterals as extrametrical, that is, unable to support a mora; onsets are universally weightless, whereas geminates are underlyingly moraic.

Some issues must be now addressed with respect to the extrametricality account. The present analysis proposes that voiced obstruents are repelled from the coda in order not to violate NoVoicEdCodA, whereas some liquids fail to be syllabified as a coda due to their extrametrical status. In both cases, vowel lengthening is triggered by the absence of a closed syllable and the need to satisfy FoотBinaRity $\mu$. However, such absence is different in nature, one due to a feature, [voice], the other to underlying extrametricality. To support this approach, we must be in the position to discard a unified analysis that treats voiced obstruents as being extrametrical like some liquids. This is in fact the case. Voiced obstruents cannot be extrametrical because they precisely undergo final devoicing, which only targets codas. If voiced obstruents were extrametrical, there would be no reason to apply final devoicing. Another possible analysis could be to consider that in (CV:L) syllables closed by a liquid the vowel is underlyingly long. This possibility must be rejected because it would entail the existence of a process of vowel shortening in non-final position (['sa:lt] 'salt' alternates with ['sale] 'make salty-3SG'). Indeed, this shortening 
process would predict that all non-final stressed vowels are short, contrary to the facts of Central Friulian (['ne:re] 'black-FEM', ['vorli] 'eye').

One might also wonder why only laterals and rhotics can be specified as extrametrical. In other words, one should ask why the invoked historical evidence that applies for liquids does not apply for nasals. The answer is that the historical evidence does hold for nasals, but it is not found in Friulian, but in Milanese. In Milanese, vowel length is contrastive before nasals and this traces back to the geminate vs. non-geminate Latin distinction (CANNAS $\rightarrow$ ['kan] 'reed.PL.' vs. $\mathrm{CANE} \rightarrow[$ 'kã: $]$ 'dog'). ${ }^{17}$

The fact that vowel length before nasals is still operative in Milanese but not in Friulian suggests that a historical vowel length neutralization process before nasals took place in favor of the least marked vowel, the short one, in Friulian. This very same neutralization process must have applied before rhotics in Milanese, where no vowel length contrast is found. Demoting FAITHFulnEss(extrametricality) relativized to nasals in Friulian and to rhotics in Milanese below ExhAustivity would explain this neutralization of vowel length. The new ranking could ultimately lead to the loss of underlying extrametricality, not learnable anymore in the absence of the vowel length contrast. ${ }^{18}$

The crucial thing here is that, if we compare Friulian with Milanese, both nasals or rhotics pattern with voiceless obstruents, and that the maintenance of vowel length contrast in laterals for both dialects and in nasals in Milanese or rhotics in conservative dialects of Friulian is a direct consequence of the historical geminate $v s$. non-geminate distinction in Latin that, when it got neutralized, obscured the facts.

Table 3 shows that there is nothing special in nasals or rhotics, which both can maintain the length contrast of the previous vowel. ${ }^{19}$

Table 2 Length before sonorants

\begin{tabular}{llll}
\hline & nasals & laterals & rhotics \\
\hline $\begin{array}{llll}\text { Conservative Friulian } \\
\text { Milanese }\end{array}$ & CVN & CVL / CV:L & CVR / CV:R \\
& CVN / Cr̃: & CVL / CV:L & CVR \\
\hline
\end{tabular}

By comparing the behavior of vowel length before sonorants in Friulian and Milanese, it seems quite clear that a hypothetical (transparent) dialect in which length was contrastive (but historically predictable) in all sonorant contexts could have existed. In fact, I suggest that this was probably the situation of Friulian and Milanese in earlier stages of development.

To sum up, the extrametricality account has two main advantages: (a) it is compatible with any sonority-based account of coda weight because it easily explains why some liquids, although

\footnotetext{
17 Milanese has a process of word-final nasal deletion before long vowels accompanied with nasal spreading onto the vowel.

18 However, neutralization in favor of the long vowel is found before rhotics in Central Friulian and before nasals in the Italian dialect of Rimini, a variety of Romagnol. Explaining the nature of this less intuitive neutralization process in favor of the long vowel goes beyond the scope of this paper. However, let me suggest two possible phonetic explanations that could had been phonologized. On the one hand, the relatively slow gesture required for rhotics can create greater coarticulation effects between the vowel and the rhotic and lengthen the vowel as a result (Koen Sebregts p.c., Recasens and Pallarès 1999). On the other hand, in Riminese, all vowels preceding nasals are long (Hajek 1997). In addition, they are always nasalized ("Contextual nasalization of all long vowels before $\mathrm{N}$ is now regular in modern Riminese" Hayek 1997:51). As a result, vowels are long and nasalized also before original geminates in Latin: ANNU $\rightarrow$ [ã:n] or [ãa:n) 'year'). The possible explanation is that vowels could have lengthened as a way to enhance nasality after spreading of [nasal] to all vowels preceding nasals, as nasalization is easier to perceive in longer vowels according to Whalen and Beddor (1989).

19 However, laterals have resisted the historical vowel length neutralization process in favor of the short vowel.
} 
being more sonorous than nasals, may sometimes be weightless; and (b), it allows for an intuitive synchronic explanation of the Latin contrast between geminates and non-geminates in Latin.

Affricates The pattern of affricates is also intriguing. Although affricates are obstruents, voiced affricates do not trigger vowel lengthening. This deviant behavior can be easily explained if affricates are assumed to have two skeletal positions and two root nodes in Friulian, and only the second root node dominates [voice]. Phonologically, there would be no difference between an affricate and a homorganic consonantal cluster (37).

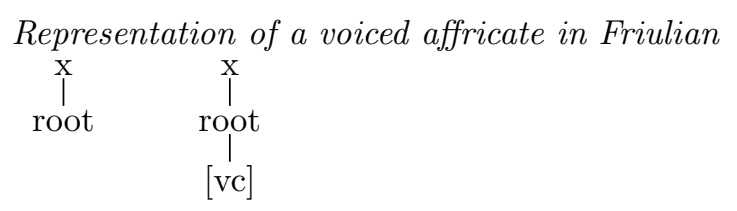

Affricates behave just like consonantal clusters in which the first element, not being voiced, can be parsed in coda position at the first step of the derivation, blocking vowel lengthening. Then the second root node is parsed and final devoicing applies to it. When the affricate surfaces in onset position, a regressive voicing assimilation process is active that spreads [voice] from the second root node to the first one. ${ }^{20}$

Assuming affricates to have two skeletal positions finds independent motivation in how borrowings are pluralized (Roseano 2014). In Friulian, there is a general process of deletion of sibilants when followed by another sibilant (/pe $\int-\mathrm{s} / \rightarrow$ ['pes] 'fish-PL'). When the English word 'badge' is borrowed in Friulian as ['be $\widehat{d}$ ]], it is pronounced as ['bedz] or ['bets] in the plural. The plural morpheme in Friulian is $/ \mathrm{s} / .{ }^{21}$ This means that the affricate in $/ \mathrm{bed}_{3} /$ must have two skeletal positions in order to allow sibilant deletion to target exclusively the second portion of the affricate when it is adjacent to the /s/ plural morpheme. If the affricate only had one skeletal position, the reason why the first portion of the affricate is preserved would remain unclear. ${ }^{22}$

Corollary To conclude this section, all the constraint rankings responsible for the distribution of vowel length in Friulian are represented as a Hasse diagram (38).

\footnotetext{
20 However, vowel lengthening occurs in verbal forms, namely in first and third person of the present indicative in conjugation III. Iosad (2012) interprets this specific vowel lengthening process as motivated by a morphological mora that must be realized in the surface.

21 English loanwords may not apply final devoicing (Roseano 2014).

22 An anonymous reviewer points out that the treatment of laterals runs counter to ROTB in the context of the rest of the analysis because it does not rule out mapping the input /la $\langle\mathrm{d}\rangle / \mathrm{to} *[$ 'la:d], an ill-formed Friulian word. An input like /la $\langle\mathrm{d}\rangle /$ should map into ['la:t] to express the fact that the absence of word-final voiced stops in Friulian is not an accidental gap but part of the speaker's phonological knowledge. This problem can be surmounted by splitting FAITHFULNESS(extrametricality) into FAIThFulness(extrametricality)/sonorant and FAITHFulness(extrametricality)/obstruent, and by ranking the latter below ExhAustivity (FAithfulnEss(extrametricality)/sonorant 》 ExHAUSTIVITY $\gg$ FAithFulNESS(extrametricality)/obstruent). This way, any extrametrical obstruent in the input will be parsed under the syllabic node to conform with ExhAustivity.
} 
(38) Friulian grammar as a Hasse diagram

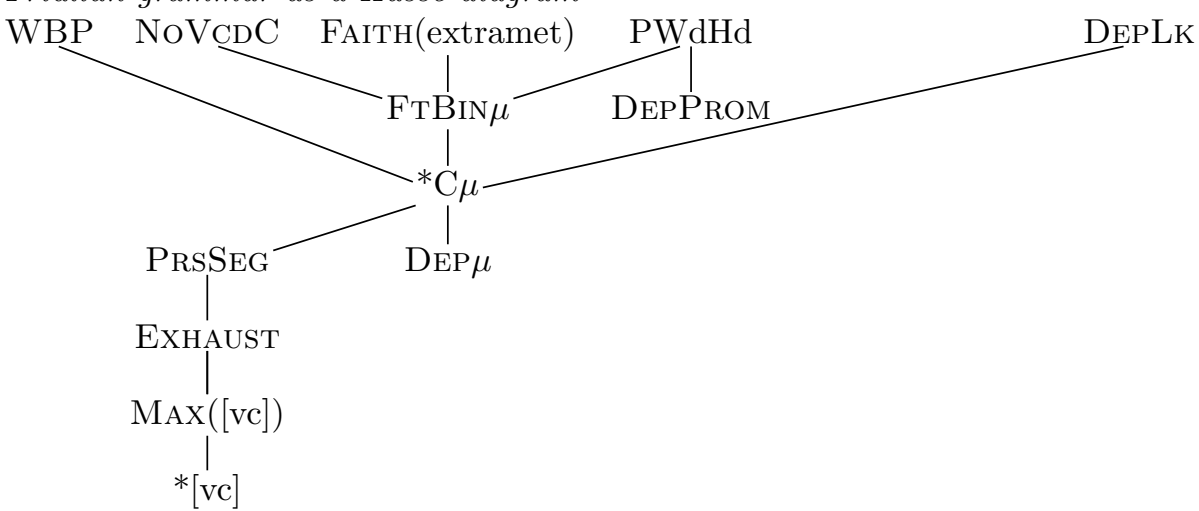

\section{Milanese}

Milanese, a dialect of Western Lombard spoken in northern Italy, is interesting for two different reasons. First, vowel lengthening always applies before underlyingly voiced obstruents, as in Friulian. Second, final devoicing is optional, subject to free variation, according to some authors (Montreuil 1991, Nicoli 1983, Prieto 2000). Some data appear in (39).

(39) Vowel length before underlyingly voiced obstruents and optional final devoicing

$\begin{array}{lllll}\text { 'nœ:v } \sim \text { 'no:f } & \text { 'new-MASC-SG' } & \text { 'nova } & \text { 'new-FEM-SG' } \\ \text { 'vi:v } \sim \text { 'vi:f } & \text { 'alive-MASC-SG' } & \text { 'viva } & \text { 'alive-FEM-SG' } \\ \text { 'tu:z } & \sim \text { 'tu:s } & \text { 'boy' } & \text { 'tuza } & \text { 'girl' } \\ \text { 'na:z } \sim \text { 'na:s } & \text { 'nose' } & \text { na'za: } & \text { 'to smell' } \\ \text { 'la:g } \sim \text { 'la:k 'lake' } & \text { lage'tin } & \text { 'lake-DIM' } \\ \text { 'fi:g } \sim \text { 'fi:k 'fig' } & \text { fi'ge: } & \text { 'fig tree' }\end{array}$

Lengthening is blocked before underlyingly voiceless obstruents, as in Friulian (40).

(40) No vowel length before underlyingly voiceless obstruents

$\begin{array}{llll}\text { 'myf 'mouldy-MASC-SG' } & \text { 'myfa } & \text { 'mouldy-FEM-SG' } \\ \text { 'pes 'fish' } & \text { pe'sam 'quantity of fish' } \\ \text { 'pas 'step' } & \text { pa'sa: 'to pass' } \\ \text { 'tas 'tax' } & \text { ta'sa: } & \text { 'to tax' } \\ \text { 'spes 'dense-MASC-SG' } & \text { 'spesa } & \text { 'dense-FEM-SG' } \\ \text { 'sak 'sack' } & \text { sa'ket } & \text { 'sack-DIM' }\end{array}$

The data in the first column in (39), with vowel lengthening but no final devoicing, seems to contradict the hypothesis entertained in this paper according to which vowel lengthening is triggered by the satisfaction of NoVOICEDCODA. On the other hand, the optional forms with final devoicing seems to support the hypothesis. However, I propose that the forms with vowel lengthening and no final devoicing contain a bisyllabic foot whose dependent syllable is degenerate, nucleusless (41). This configuration is also proposed for French in Féry (2003). 
(41) Degenerate syllable in Milanese<smiles>C1CC2(C1)OCOO2</smiles>

The prosodic configuration in (41) is also triggered by the satisfaction of top-ranked NoVoICEDCODA. However, to prevent final devoicing plus coda adjunction, the anti-devoicing faithfulness constraint $\operatorname{MAx}([$ voice] $)$ must dominate the markedness constraint against degenerate syllables, SyllableHead (42). The tableau (43) shows the third step of the derivation in Milanese, after vowel lengthening has applied to satisfy NoVoicedCoda and FootBinarity $\mu$. A voiced obstruent is parsed as a degenerate syllable, candidate (a), instead of being devoiced and parsed to the already existing syllable, candidate (b), which would correspond to the Friulian solution.

(42) SyllableHead (SyllHd)

Assign one violation mark for every syllable that does not dominate at least one mora. (Elfner 2009)

(43) Step $3(\operatorname{Max}([$ voice $]) \gg$ SyllableHead $)$

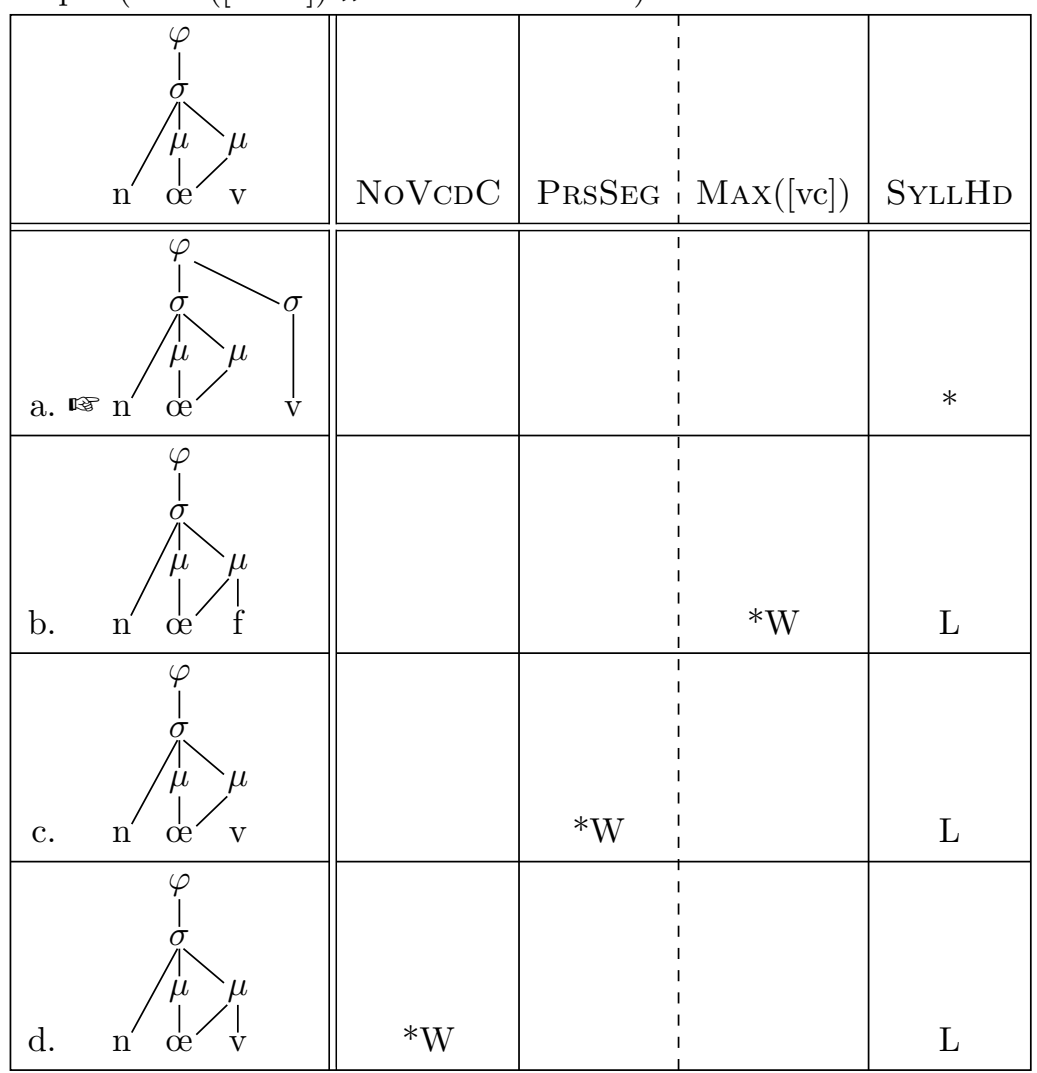

In order to explain the optionality of final devoicing, I make use of Serial Variation (SV) (Kimper 2011). SV combines HS with the Partially Ordered Constraint model of phonological 
variation developed in Anttila (1997). In the Partially Ordered Constraints model, a grammar may contain partial rankings. From partial rankings of constraints, different total orders are possible. In SV, each time a candidate set is evaluated, a total ranking consistent with the partial ranking is randomly chosen. Phonological variation arises precisely when total orders disagree about the preferred candidate.

Following SV, I propose that the grammar of Milanese contains a partial order between $\operatorname{Max}([$ voice] $]$ and SyllableHEAD. At each step of the derivation, Eval randomly imposes a total order between these two constraints, either SYLLABLEHEAD $\gg \operatorname{MAx}([$ voice] $)$ or MAX $([$ voice] $) \gg$ SyllableHead. Each time Eval applies through the same derivation, either the non-partial grammar in (44) or the one in (45) is chosen.

(44) Total order 1 in Milanese

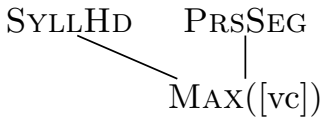

(45) Total order 2 in Milanese

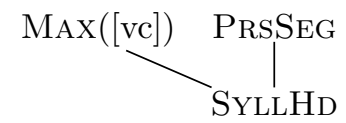

The other constraints are ranked as in Friulian. The total order between MAx([voice]) and SyllableHEAD is irrelevant at the first two steps of the derivation because first NoVoicedCodA and FootBinarity $\mu$ must be satisfied. ${ }^{23}$ However, it becomes decisive at the third step. As opposed to the tableau (43), if SyllableHEAD dominates MAX([voice]), then final devoicing plus coda adjunction applies, and the outcome is identical to that in Friulian (46).

(46) Step 3 (SyllableHEAD $\gg \operatorname{Max}([$ voice $]))$

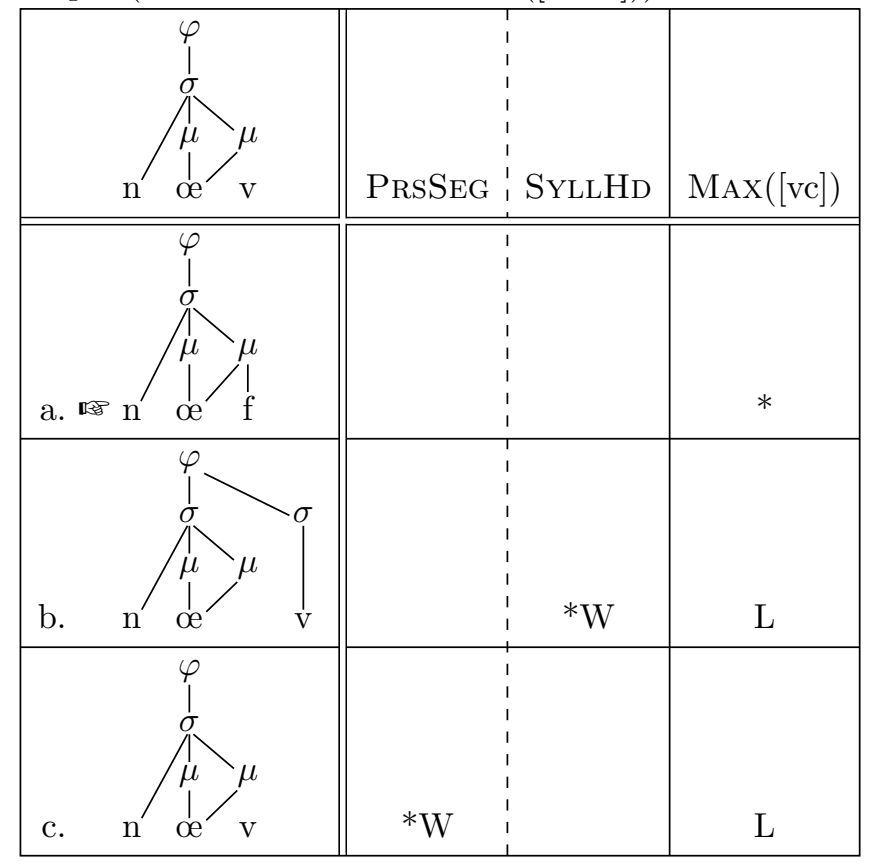

23 At the first step, $\left(\operatorname{lo}_{\mu}\right)(\mathrm{v})$, with a degenerate foot and a degenerate syllable, ties with $\left(\mathrm{lo}_{\mu}\right) \mathrm{v}$, with the voiced obstruent left unparsed, according to the ranking in (44). I obviate this tie for clarity and assume that only (lo $\mu$ ) $\mathrm{v}$ is selected as the winning candidate. The tie does not make the arguments invalid. 
At the next step of the derivation, a total ordering is randomly chosen by EvAL again. If the ranking between SyllableHEAD and MAX([voice]) is left intact, convergence is guaranteed after (43) and (46). However, when the ranking between these two constraints contradicts the ranking selected at the previous step, only the derivation in (46) converges at the fourth step (47).

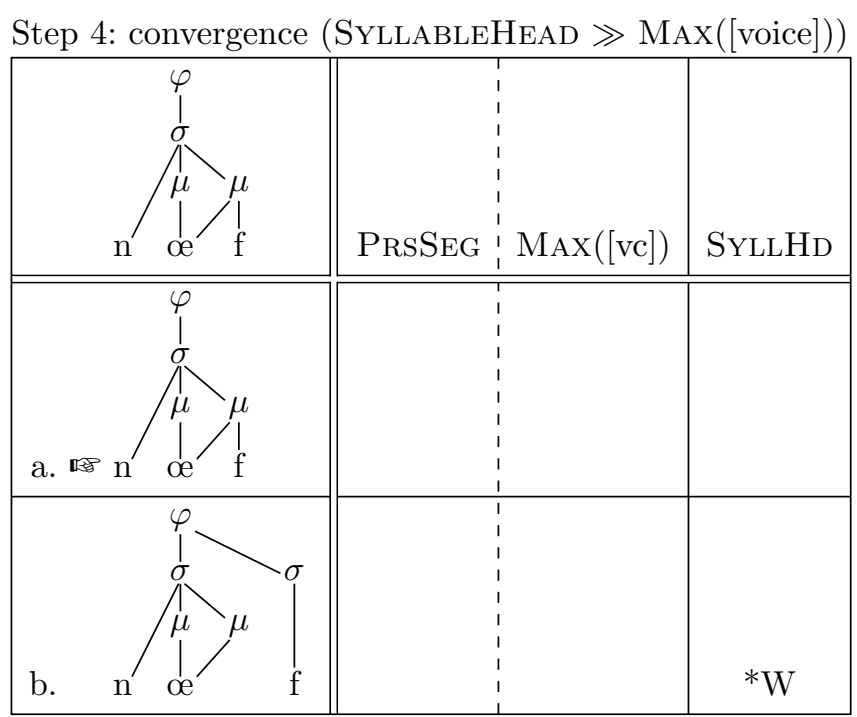

However, the derivation in (43) only converges at the fourth step if the ranking MAx([voice]) $\gg$ SYLLABLEHEAD is maintained. If it is reversed, the candidate with final devoicing, in which the degenerate syllable is deleted and the obstruent is integrated as a coda, is the optimal candidate (48).

(48) Step 4: non-convergence (SYLlableHEAD $\gg \operatorname{MAX}([$ voice] $])$

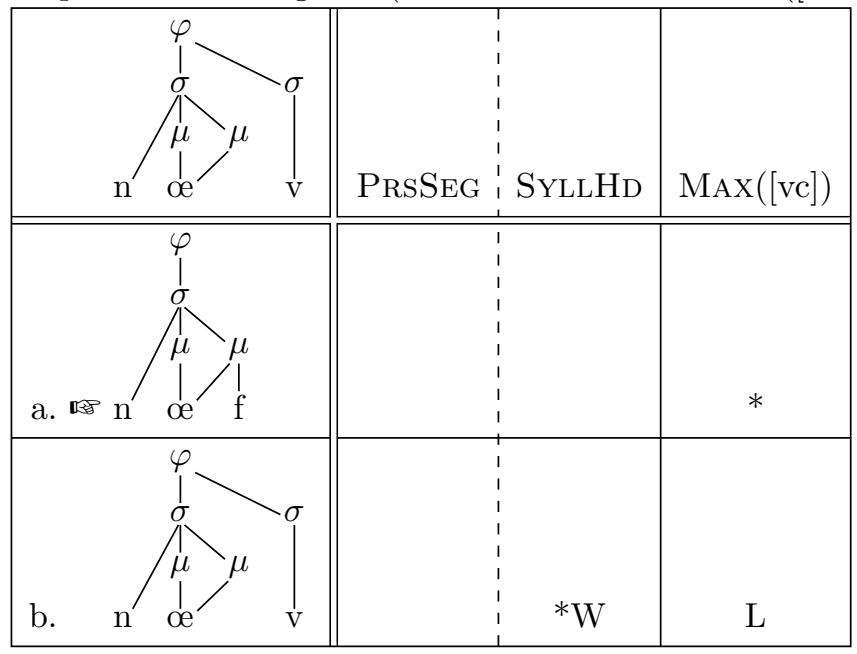

At the fifth step, the derivation converges no matter the total order of constraints that is imposed.

SV is a good theory to model both optional final devoicing in Milanese and at the same time deriving vowel lengthening from the independent need of satisfying NoVorCEDCODA and FootBinarity $\mu$ even in those cases in which there is no final devoicing. 
To sum up, the analysis in SV works as follows. At the first two steps, the ranking between SyllableHead and Max ([voice]) is irrelevant because first ProsodicWordHead and NoVoicedCoda must be satisfied, and then FootBinarity $\mu$. The partially ranked constraints are too low in the hierarchy to become decisive at the first steps. The two different total orders select different winner candidates at the third step of the derivation. If SyllableHEAD dominates $\operatorname{Max}([$ voice]), coda adjunction and final devoicing is more harmonic. Once this form is selected as optimal, the derivation will converge at the next step regardless of the total ranking selected because (nó:f) violates neither SyllableHead nor Max([voice]). If MAx([voice]) dominates SyllableHeAD, then the voiced obstruent is parsed as a degenerate syllable. The same ranking at the next step will convergence on the same candidate. The selection of the opposite total order will select the candidate with coda adjunction plus devoicing, which in turn will converge at the next step. Convergence is therefore always guaranteed. ${ }^{24}$ The SV derivations after the first two steps are illustrated in (49).

$S V$ derivations after step 1 and 2

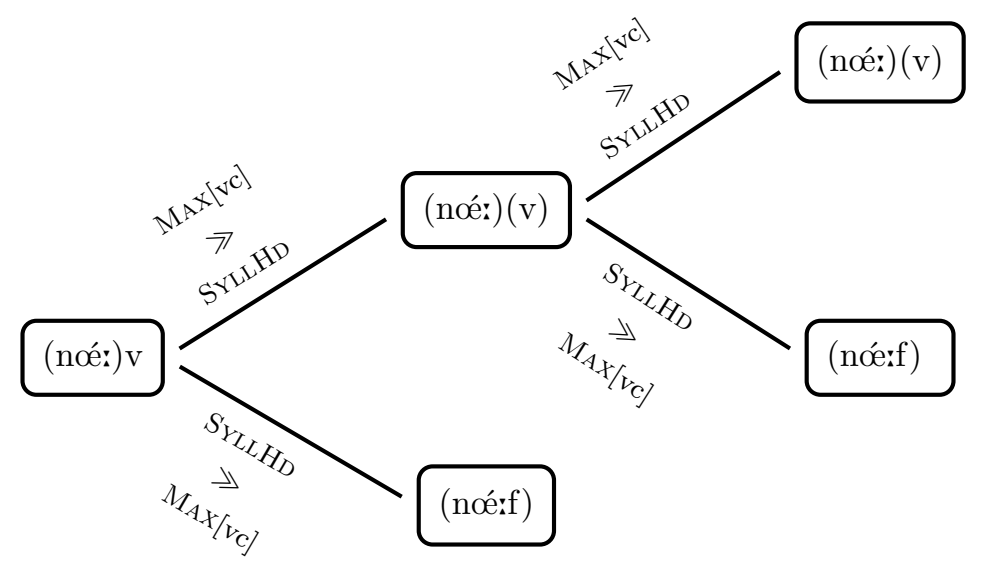

The complete typology on the interaction between vowel lengthening and final devoicing can be illustrated with a set of Eastern dialects of Lorrain French (Montreuil 2010, Lanher 19791989). Four different dialects correlate with the four possible interactions between these two processes, as shown in table (3).

Table 3 Lorrain French (Montreuil 2010)

\begin{tabular}{llll}
\hline & Lengthening & Devoicing & \\
\hline Southern Lorraine & $\checkmark$ & $X$ & ['ba:g] \\
Eastern Lorraine & $\checkmark$ & $\checkmark$ & ['ba:k] \\
Western Lorraine & $X$ & $X$ & ['bag] \\
Northwestern Lorraine & $\times$ & $\checkmark$ & ['bak] \\
\hline
\end{tabular}

The pattern found in Eastern Lorraine French is like the one in Friulian, and Southern Lorraine French coincides with one of the optional forms in Milanese. The last two patterns correspond to cases without vowel lengthening, Western Lorraine French lacking final devoicing,

\footnotetext{
24 As one anonymous reviewer points out, this is only technically true if no other rankings freely vary.
} 
as opposed to Northwestern Lorraine French. To get no lengthening and no devoicing, FootBINARITY $\mu$ must dominate both ${ }^{*} \mathrm{C} \mu$ and NoVoicEdCodA, DePLink must dominate ${ }^{*} \mathrm{C} \mu$, and $\operatorname{Max}([$ voice] $)$ and SyllableHead must dominate NoVoicedCoda. To get no lengthening but devoicing, NoVoicedCoda must be ranked above MAx([voice]).

A potential unattested pattern in which lengthening only occurs before underlyingly voiceless obstruents cannot be derived by any permutation of the constraint set presented so far. In conclusion, the whole set of possibilities regarding the interaction between vowel lengthening and final devoicing finds a straightforward explanation in HS, including the opaque interaction. Moreover, transparent vowel lengthening before underlyingly voiced obstruents that do not devoice is also triggered by universal NoVorcedCODA, although this constraint is not necessarily satisfied by means of final devoicing but by parsing the voiced obstruent as a degenerate syllable.

The next section discusses the most recent account of the Friulian data (Iosad 2012) and proposes an alternative analysis that considers final devoicing in Milanese to be gradual, as opposed to Friulian.

\section{Discussion and alternative}

In this section, I will concentrate on discussing the most in-depth analysis of the whole set of vowel lengthening phenomena in Friulian, the one in Iosad (2012), and I will also propose an alternative analysis of the facts in terms of turbid representations.

\subsection{Iosad's (2012) POT analysis}

Iosad (2012) argues in favor of a representational solution to (apparent) opacity. He relies on a three-way distinction among obstruents that reflects the phonetic findings in Baroni and Vanelli (2000), which report that devoiced obstruents are shorter than underlyingly voiceless obstruents and show weaker bursts, although they devoice completely. ${ }^{25}$ For this reason, they assume incomplete neutralization. These representations are given in (50). From left to right, devoiced, voiced, and voiceless obstruents.

(50) Laryngeal three-way distinction among obstruents (Iosad 2012)

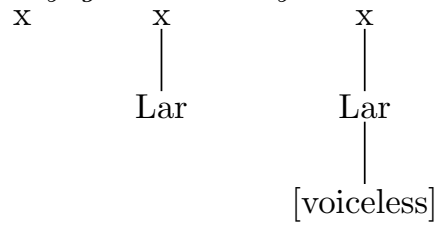

According to Iosad (2012), final devoicing in Friulian is not a laryngeal neutralization process, but a type of selective markedness reduction process that consists on deleting the node Lar. Voiceless obstruents are immune to this process. This result is obtained with the following ranking: MAx[voiceless] $\gg *$ ALIGN-Right(Word-Lar) $\gg \operatorname{MAx}($ Lar). *ALIGN-Right(Word-Lar) triggers deletion of Lar. Its definition appears below.

(51) *ALIGN-Right(Word-Lar)

Assign one violation mark for every Lar node that is aligned with the right edge of a word. (Iosad 2012)

25 The phonetic findings in Baroni and Vanelli (2000) are based on only one speaker. A replication of the experiment with more speakers and more conditions is called for in order to confirm their results. 
The fact that deletion of [voiceless] is prohibited due to top-ranked MAx[voiceless], and given that deletion of Lar also implies deletion of [voiceless] according to the representations in (50), voiceless obstruents surface faithfully as such, while devoiced obstruents are those that lose Lar. Consider (52). Candidate (c) violates WeightByPosition(Lar) because the voiced obstruent [d], that contains Lar, does not project a mora. This candidate also violates *ALIGNRight(Word-Lar). Candidates (b) and (a) delete Lar ([d] $]$ ). This is marked with the voiceless diacritic. Devoiced obstruents laking Lar vacuously satisfy WEIGHTBYPosition(Lar) but violate $\operatorname{MAx}($ Lar). The constraint $* \mu[$ consonant $]$ favors candidate (a), with vowel lengthening instead of weight by position, over candidate (b).

(52) POT analysis of /lad/ (based on Iosad 2012)

\begin{tabular}{|c|c|c|c|c|}
\hline /lad/ & 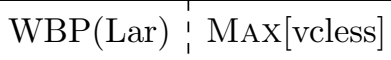 & ${ }^{*} \mathrm{AL}-\mathrm{R}(\mathrm{W}-\mathrm{Lar})$ & $\operatorname{MAx}($ Lar $)$ & $* \mu[\mathrm{cons}]$ \\
\hline a. $\operatorname{la}_{\mu \mu} \mathrm{d}$ & 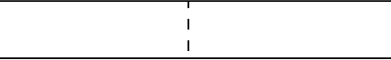 & & $*$ & \\
\hline b. $\quad \operatorname{la}_{\mu} \mathrm{d}_{\mu}$ & $\begin{array}{l}1 \\
1\end{array}$ & & $*$ & $* \mathrm{~W}$ \\
\hline c. $\quad \operatorname{la}_{\mu \mu} \mathrm{d}$ & $* \mathrm{~W}$ & $* \mathrm{~W}$ & $\mathrm{~L}$ & \\
\hline
\end{tabular}

Preservation of [voiceless] is illustrated in tableau (53). The last two candidates with vowel lengthening fatally violate WeightByPosition(Lar), because these obstruents contain the node Lar and they do not project a mora. Only candidates (a) and (b) satisfy this constraint, the former because the voiceless obstruent projects a mora, and the latter because the devoiced obstruent, even though it does not project a mora, vacuously satisfies WeIGHTBYPosition(Lar) because it lacks this node. However, candidate (b) is ruled out because it fatally violtes MAx[voiceless], which is ranked above *ALIGN-Right(Word-Lar).

POT analysis of /lat/ (based on Iosad 2012)

\begin{tabular}{|c|c|c|c|c|c|}
\hline /lat/ & WBP(Lar) & MAX[vcless] & ${ }^{*} \mathrm{AL}-\mathrm{R}(\mathrm{W}-\mathrm{Lar})$ & MAx(Lar) & $* \mu[\mathrm{cons}]$ \\
\hline a. $\mathrm{la}_{\mu} \mathrm{t}_{\mu}$ & & & $*$ & & * \\
\hline b. $\quad l \mathrm{a}_{\mu \mu} \mathrm{d}$ & & ${ }^{*} \mathrm{~W}$ & $\mathrm{~L}$ & ${ }^{*} \mathrm{~W}$ & $\mathrm{~L}$ \\
\hline c. $\quad \operatorname{la}_{\mu \mu} \mathrm{t}$ & $* \mathrm{~W}$ & & $*$ & & $\mathrm{~L}$ \\
\hline d. $\quad l \mathrm{a}_{\mu \mu} \mathrm{d}$ & $* \mathrm{~W}$ & $* \mathrm{~W}$ & $*$ & & $\mathrm{~L}$ \\
\hline
\end{tabular}

In what follows, I express my concerns regarding such an analysis by addressing what I see as two typological inadequacies.

First, the analysis in Iosad (2012) assumes voiceless obstruents to be more complex than voiced obstruents in featural terms. It is generally assumed that more complex segments, being more marked, always presuppose the existence of less complex segments, which are less marked. However, only the presence of voiced obstruents in the sound systems of language implies the presence of voiceless segments, and not the other way around. Moreover, Iosad (2012) does not make explicit why a more standard analysis using [voice] is not considered.

Second, the analysis also assumes that only voiceless segments can support a mora. This follows from WeightByPosition(Lar) being ranked above * $\mu$ [consonant]. Devoiced obstruents do not support a mora because they gratuitously violate $* \mu$ [consonant], as shown by comparing candidates (a) and (b) in (52), which satisfy WeightByPosition(Lar) without the need to project a mora. Vowels then lengthen to satisfy FootBinarity $\mu$, not included in the previous tableaux. However, relativizing WeightByPosition according to Lar leads to pathological systems. Given that sonorants lack any laryngeal specification in privative feature theories, a 
language in which voiceless obstruents contribute to weight, but not sonorants, is predicted. A system like this does not seem to exist. In fact, if obstruents license moras, so do sonorants, but not the other way around (Zec 1995). As opposed to Iosad (2012), the present approach does not stipulate that only voiceless obstruents license moras, and it maintains a more established view of devoiced obstruents as segments lacking the feature [voice]. The present analysis is also consistent with Zec's (1995) observation that weight and sonority are intimately related. The puzzling distribution of sonorants with respect to weight in Friulian and Milanese is not explained by relativizing WeightByPosition to manner specifications, as in Iosad (2012), but as faithfulness to underlying extrametricality, as exposed in §3. Iosad (2012) relativizes WeightByPosition to manner specifications in order to explain the puzzling weight distribution of sonorants in Friulian (WeigthByPosition[lateral] $\gg * \mu$ [consonant] $\gg$ WeightByPosition[rhotic] for liquids). However, his approach predicts many types of systems inconsistent with the fact that more sonorous segments are more prone to license weight than less sonorous segments. The analysis in this paper takes a different position by adducing lexical extrametricality as a synchronic reanalysis of a geminate $v s$. non-geminate opposition in Latin. The relation between sonority and weight should be expressed as in (54), in terms of fixed rankings where ${ }^{*} \mathrm{C} \mu$ is relatived with respect to sonority classes. ${ }^{26}$ In Friulian, WeightByPosition outranks all ${ }^{*} \mathrm{C} \mu$ constraints because all consonants are weight-contributing.

$$
\begin{array}{llllll}
\text { Typology of moraic elements } & & & & & \\
\text { All segments (Friulian) } & \mathrm{WBP} & { }^{*} \mathrm{C}_{\text {Obstr }} \mu & \gg{ }^{*} \mathrm{C}_{\text {Son }} \mu \\
\text { Only vowels and sonorants } & { }^{*} \mathrm{C}_{\text {Obstr }} \mu & \gg & \mathrm{WBP} & \gg{ }^{*} \mathrm{C}_{\text {Son }} \mu \\
\text { Only vowels } & { }^{*} \mathrm{C}_{\text {Obstr }} \mu & \gg & { }^{*} \mathrm{C}_{\text {Son }} \mu & \gg & \mathrm{WBP}
\end{array}
$$

5.2 The phonology-phonetics interface and the nature of final devoicing

The Milanese data in $\S 4$ has been described as showing a categorical two-way distinction between devoiced obstruents and voiced obstruents in coda position, subject to free variation. This is the way Nicoli (1983), Montreuil (1990) and Prieto (2000) interpret the data. However, Pavia (1928) and Sanga (1988) report that final devoicing in Milanese is not categorical: "In milanese le consonanti finali mantengono la sonorità in maniera variabile [...]: o restano sonore, o passano a sorde, o hanno una realizzazione intermedia [...]; in ogni caso vi è una forte variabilità [...]" (Sanga 1988:295). ${ }^{27}$

Very interestingly, this variation has not been reported for Friulian. What Baroni and Vanelli (2000) report is that devoiced obstruents, when compared to voiceless obstruents, are shorter and show weaker bursts when compared to truly voiceless obstruents. But crucially they did not find any voicing during closure in devoiced obstruents. I argue that final devoicing in these two languages is different in nature: categorical in Friulian but gradual in Milanese.

Van Oostendorp (2008) argues in favor of Turbidity Theory as a phonetics-free model of formal phonology that can easily incorporate incomplete neutralization. In Turbidity Theory (Goldrick 2001), features are underlyingly linked to root nodes by a projection relation, but these features are realized in the surface only if a pronunciation relation between them and root nodes is positionally licensed. Final devoicing is the result of not inserting a pronunciation

\footnotetext{
26 Here I use universally fixed constraints, but non-fixed constraints in a stringency relation could also be posited: $\left[{ }^{*} \mathrm{C}_{\text {Obstruent }} \mu,{ }^{*} \mathrm{C}_{\text {Sonorant }} \mu\right],\left[{ }^{*} \mathrm{C}_{\text {Obstruent }} \mu\right]$. WeightByPosition, instead of ${ }^{*} \mathrm{C} \mu$, could also be relativized to sonority to obtain the same effects.

27 "In Milanese, final consonants maintain their sonority in a variable way [...]: either they remain voiced, or devoice, or have an intermediate realization [...]; there is in general a high degree of variability [...]". The translation is mine.
} 
relation between an obstruent in coda position and the feature [voice]. Final devoicing derives from ranking NoVoICEDCODA above RECIPROCITY[voice] (55). The turbid representations of voiced and devoiced obstruents appear in (56). Upward arrows indicate projection relations and downward arrows indicate pronunciation relations.

(55) Reciprocity[voice] (REC[vc])

Assign one violation mark for every feature [voice] that is projected by a root node and is not pronounced by that root node. (van Oostendorp 2008)

(56) Turbid representations of voiced and devoiced obstruents<smiles>[Y][Al]</smiles>

Projection and pronunciation relations were first introduced to account for phonological opacity (Goldrich 2001), but they can also derive the difference between devoiced and voiceless obstruents (van Oostendorp 2008). If a feature [voice] is not pronounced but projected, then it can still be interpreted by the phonetics. However, it is interpreted gradually, in a non-uniform way. If the feature [voice] is parsed by the phonology, then it is categorically interpreted by the phonetics. The difference between final devoicing in Friulian and Milanese could therefore be represented as deletion of [voice] in the case of Friulian and maintenance of [voice] but absence of pronunciation in Milanese. These different representations would explain the variation in the realization of word-final obstruents with respect to its devoiced character. The Friulian and Milanese outputs could be represented as in $(57) .^{28}$

Categorical vs. gradual final devoicing in Friulian and Milanese

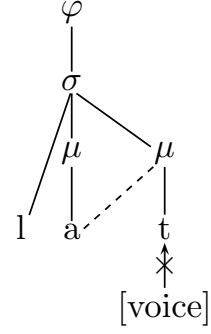<smiles>Cl[Te]O[Te]O[Te]</smiles>

The above representations should be obtained serially. HS is still needed to explain vowel lengthening as a side effect of not permitting voiced obstruents to occupy a coda position. In Milanese, where deletion of [voice] is protected by the ranking MAX([voice]) 》 RECIPROCITY[voice], a degenerate syllable hosts the devoiced obstruent to still satisfy NoVoICEDCodA. ${ }^{29}$ In Milanese, both NoVoicedCodA and Max([voice]) should dominate ReCIPROCITY([voice]) (58).

\footnotetext{
28 I assume a version of Turbidity Theory in which features can be deleted.

29 I assume that NoVOICEDCODA is violated whenever an obstruent in coda position contains a feature [voice], either pronounced, or not, in which case RECIPROCITY ([voice]) is also violated.
} 
(58) Not pronunciation of [voice] in Turbidity Theory (Milanese)

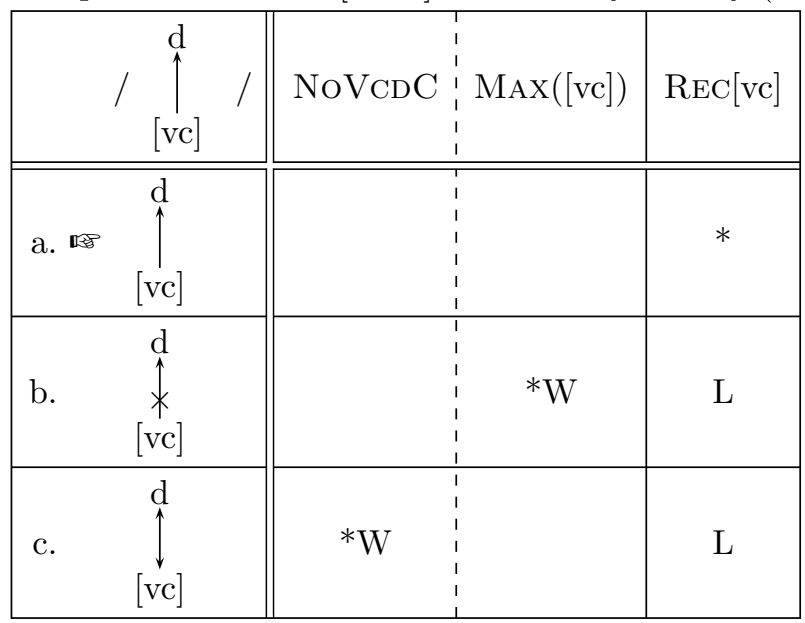

In Friulian, where [voice] deletes, the devoiced obstruent can be integrated as a coda consonant. However, NoVoicedCodA and ReCiprocitiy ([voice]) should rank above MAx([voice]) to get categorical final devoicing (59).

(59) Deletion of [voice] in Turbidity Theory (Friulian)

\begin{tabular}{|c|c|c|c|}
\hline$/ \varlimsup_{[\mathrm{vc}]}^{\mathrm{d}} /$ & NoVCDC & REC $[\mathrm{vc}]$ & $\operatorname{MAx}([\mathrm{vc}])$ \\
\hline a. $\begin{array}{c}\mathrm{d} \\
\uparrow \\
{[\mathrm{vc}]}\end{array}$ & & $\begin{array}{l}a_{1} \\
\vdots \\
1 \\
1 \\
1\end{array}$ & $*$ \\
\hline b. $\quad \uparrow_{[\mathrm{vc}]}^{\mathrm{d}}$ & & $\begin{array}{l}* \mathrm{~W} \\
\vdots\end{array}$ & $\mathrm{L}$ \\
\hline c. $\quad \varliminf_{[\mathrm{vc}]}^{\mathrm{d}}$ & ${ }^{*} \mathrm{~W}$ & $\begin{array}{l}1 \\
\vdots \\
1 \\
1\end{array}$ & $\mathrm{~L}$ \\
\hline
\end{tabular}

Representing gradual devoicing formally (in the way Turbidity Theory does) allows us to characterize phonetics as a one-to-one interpretative component which only has access to the output of the phonological grammar, and to maintain formal phonology as a simpler and more precise theory of sound systems. ${ }^{30}$ Moreover, if feature deletion is also allowed in Turbidity Theory, together with non-pronunciation of features, a clear distinction between categorical and gradual final devoicing is neatly expressed in the phonology. ${ }^{31}$

30 This is in fact the position of van Oostendorp (2008): "Just delegating these facts [incomplete neutralization] to the phonetics will mean that the phonetics has access to many types of information which is purely lexical and in a way vindicate the functionalist position: if the phonetics can see all this information anyway, why would we need the phonology to manipulate them as well?" (van Oostendorp 2008:1372).

31 I leave for future research an experimental investigation of the facts to test the nature of final devoicing in Friulian and Milanese. 


\section{Conclusion}

This paper has developed a Harmonic Serialism analysis of the opaque interaction between vowel lengthening and final devoicing in Friulian, and extended the analysis to Milanese using Serial Variation. It has been shown that constraint satisfaction through a serial derivation accounts for a case of cross-level opaque interaction straightforwardly. I have shown that only Harmonic Serialism is able to derive vowel lengthening as a biproduct of satisfying the independently needed constraints NoVoicedCodA and FootBinarity $\mu$. Previous parallel accounts cannot maintain uniformity in the representation of devoiced and voiceless obstruents at the level of featural composition and at the moraic tier. Furthermore, introducing turbid representations seems to give a more accurate picture of the facts by deriving categorical vs. gradual final devoicing in Friulian and Milanese, respectively.

Acknowledgements I am thankful to Patrice Beddor, Eulàlia Bonet, Ben Hermans, Pavel Iosad, Peter Jurgec, Kathrin Linke, Joan Mascaró, Marc van Oostendorp, Clàudia Pons-Moll, Douglas Whalen, three anonymous reviewers for their comments on this work, and especially to Michael Kenstowicz, the associate editor of this paper. I also thank the audience at the 20th Manchester Phonology Meeting. Further thanks are due to Paolo Roseano for help clarifying aspects of the Friulian data. All errors remain mine. I dedicate this paper to the memory of my mother.

\section{References}

Anttila, Arto. 1997. Deriving variation from grammar. In Variation, change and phonological theory, eds. Frans L. Hinskens, Roeland van Hout and W. Leo Wetzels, 35-68. Amsterdam: John Benjamins.

Baroni, Marco, and Laura Vanelli. 2000. The relationship between vowel length and consonantal voicing in Friulian. In Phonological theory and the dialects of Italy, ed. Lori Repetti, 13-44. Amsterdam: John Benjamins.

Bermúdez-Otero, Ricardo. 2001. Underlyingly nonmoraic coda consonants, faithfulness, and sympathy. Ms., University of Manchester, Manchester.

Broselow, Su-I Chen, and Marie Huffman. 1997. Syllable weight: Convergence of phonology and phonetics. Phonology 14: 47-82.

Campos-Astorkiza, Rebeka. 2004. Faith in moras: A revised approach to prosodic faithfulness. In Proceedings of the North East Linguistic Society 34, eds. Keir Moulton and Matthew Wolf, 47-82. Amherst: GLSA Publications.

Dow, Michael. 2013. Multiple repairs for voiced obstruent codas in Berbice Dutch Creole. Paper presented at The 21st Manchester Phonology Meeting, May 2013.

Elfner, Emily. 2006. Contrastive syllabification in Blackfoot. In Proceedings of the 25th West Coast Conference on Formal Linguistics, eds. Donald Baumer, David Montero, and Michael Scanlon (eds), 141-149. Somerville: Cascadilla Press.

Elfner, Emily. 2009. Syllabification and stress-epenthesis interations in Harmonic Serialism. Ms., University of Massachusetts, Amherst.

Elfner, Emily. Forthcoming. Stress-epenthesis interactions in Harmonic Serialism. In Harmonic Grammar and Harmonic Serialism, eds. John J. McCarthy and Joe Pater. London: Equinox Publishing.

Elsman, Minta. Forthcoming. Parallelism vs. serialism, or constraints vs. rules? In Harmonic Grammar and Harmonic Serialism, eds. John J. McCarthy and Joe Pater. London: Equinox Publishing. 
Féry, Caroline. 2003. Markedness, faithfulness, vowel quality and syllable structure in French. Journal of French Language Studies 13: 247-280.

Finco, Franco. 2009. Fonetiche e fonologjie dal furlan centrâl. Gjornâl furlan des siencis 11: 53-85.

Goldrick, Matthew. 2001. Turbid output representations and the unity of opacity. In NELS 30, eds. Masako Hirotani, Andries Coetzee, Nancy Hall, and Ji-Yung Kim. Amherst: GLSA, 231-245.

Hajek, John. 1997. Universals of sound change in nasalization. Oxford: Blackwell Publishing.

Hayes, Bruce. 1989. Compensatory lengthening in moraic phonology. Linguistic Inquiry 20: 253306.

Hualde, José I. 1990. Compensatory lengthening in Friulian. Probus 2: 31-46.

Inkelas, Sharon, C. Orhan Orgun, and Cheryl Zoll. 1997. The implications of lexical exceptions for the nature of grammar. In Derivations and constraints in phonology, ed. Iggy Roca, 393-418. Oxford: Clarendon.

Iosad, Pavel. 2012. Final devoicing and vowel lengthening in Friulian: A representational approach. Lingua 122: 922-951.

Jesney, Karen. 2011. Positional Faithfulness, non-locality, and the Harmonic Serialism solution. In Proceedings of the North East Linguistics Society 39, eds. Suzi Lima, Kevin Mullin and Brian Smith, 429-440. Amherst: GLSA Publications.

José, Brian, and Julie Auger. 2004. (Final) nasalization as an alternative to (final) devoicing: The case of Vimeu Picard. Indiana Working PApers in Linguistics, 4(3): 1-44.

Kimper, Wendel A. 2011. Locality and globality in phonological variation. Natural Language 86 Linguistic Theory 29: 423-465.

Kouwenberg, Silvia. 1994. A grammar of Berbice Dutch Creole. Berlin: Mouton de Gruyter.

Lanher, Jean, Alain Litaize, and Jean Richard. Atlas linguistique et ethnographique de la Lorraine Romane. Paris: CNRS.

Lombardi, Linda. 1999. Positional faithfulness and the phonology of voicing in Optimality Theory. Natural Language \& Linguistic Theory 17: 267-302.

Lombardi, Linda. 2001. Why place and voice are different: Constraint-specific alternations in Optimality Theory. In Segmental phonology in Optimality Theory, ed. Linda Lombardi, 1345. Cambridge: Cambridge University Press.

McCarthy, John J., and Alan Prince. 1996. Prosodic morphology. In The handbook of phonological theory, ed. John A. Goldsmith, 102-136. Oxford: Blackwell Publishing.

McCarthy, John J. 2007. Hidden generalizations: Phonological opacity in Optimality Theory. London: Equinox Publishing.

McCarthy, John J. 2008a. The serial interaction of stress and syncope. Natural Language $\&$ Linguistic Theory 26: 499-546.

McCarthy, John J. 2008b. Doing Optimality Theory: Applying theory to data. Malden: Blackwell Publishing.

McCarthy, John J. 2009. Studying Gen. Journal of the Phonetic Society of Japan 13: 3-12.

McCarthy, John J. 2010. An introduction to Harmonic Serialism. Ms., University of Massachusetts, Amherst.

McCarthy, John J. Forthcoming. The theory and practice of Harmonic Serialism. In Harmonic Grammar and Harmonic Serialism, eds. John J. McCarthy and Joe Pater. London: Equinox Publishing.

Montreuil, Jean-Pierre Y. 1991. Length in Milanese. In New analyses in Romance linguistics, eds. Dieter Wanner and Douglas A. Kibbee, 37-47. Amsterdam: John Benjamins. 
Montreuil, Jean-Pierre Y. 2010. Multiple opacity in Eastern Regional French. In Romance Linguistics 2009, eds. Sonia Colina, Antxon Olarrea and Ana M. Carvalho, 153-166. Amsterdam: John Benjamins.

Morén, Bruce T. 1999. Distinctiveness, coercion and sonority: A unified theory of weight. PhD dissertation, University of Maryland, College Park.

Nicoli, Franco. 1983. Grammatica milanese. Busto Arsizio: Bramante Editrice.

van Oostendorp, Marc. 200X. Restricting repairs. Ms., Meertens Institute, Amsterdam.

van Oostendorp, Marc. 2008. Incomplete devoicing in formal phonology. Lingua 118: 1362-1374.

Pater, Joe. 2012. Serial harmonic grammar and Berber syllabification. In Prosody matters: Essays in honor of Elisabeth Selkirk, eds. Toni Borowsky, Shigeto Kawahara, Takahito Shinya, and Mariko Sugahara, 43-72. London: Equinox Publishing.

Pater, Joe. Forthcoming. Universal Grammar with weighted constraints. In Harmonic Grammar and Harmonic Serialism, eds. John J. McCarthy and Joe Pater. London: Equinox Publishing.

Pavia, Luigi. 1928. Sulla parlata milanese e suoi connessi: Nuovi studî fonico-grafici, filologici, storici, comparativi. Bergamo: presso l'Autore.

Prieto, Pilar. 1992. Compensatory lengthening by vowel and consonant loss in early Friulian. Catalan Working Papers in Linguistics 2: 205-244.

Prieto, Pilar. 1994. Vowel lengthening in northern Italy: A case for segmental and prosodic optimization. PhD dissertation, University of Illinois, Urbana Champaign.

Prieto, Pilar. 2000. Vowel lengthening in Milanese. In Phonological theory and the dialects of Italy, ed. Lori Repetti, 255-272. Amsterdam: John Benjamins.

Prince, Alan. 1983. Relating to the grid. Linguistic Inquiry 14: 19-100.

Prince, Alan. 2002. Arguing optimality. In University of Massachusetts occasional papers in linguistics: Papers in Optimality Theory II, eds. Angela Carpenter, Andries Coetzee, and Paul de Lacy, 269-304. Amherst, MA: GLSA.

Pruitt, Kathryn. 2010. Serialism and locality in constrained-based metrical parsing. Phonology 27: 481-526.

Pruitt, Kathryn. 2012. Stress in Harmonic Serialism. PhD dissertation, University of Massachusetts, Amherst.

Recasens, Daniel, and Pallarès, Maria Dolors. 1999. A study of $/ \mathrm{r} /$ and $/ \mathrm{rr} /$ in the light of the 'DAC' coarticulation model. Journal of Phonetics 27: 143-169.

Repetti, Lori. 1992. Vowel length in northern Italian dialects. Probus 4: 155-182.

Repetti, Lori. 1994. Degenerate syllables in Friulian. Linguistic Inquiry 25: 186-193.

Roseano, Paolo. 2014. Can morphological borrowing be an effect of codeswitching? Evidence from the inflectional morphology of borrowed nouns in Friulian. Probus 26: 1-58.

Sanga, Glauco. 1988. La lunghezza vocalica nel milanese e la coscienza dei parlanti. Romance Philology 41: 290-297.

Selkirk, Elisabeth. 1995. The prosodic structure of function words. In University of Massachusetts occasional papers in Optimality Theory, eds. Jill N. Beckman, Laura W. Dickey and Suzanne Urbanczyk, 21-51. Amherst, MA: GLSA.

Steriade, Donca. 2001. The phonology of perceptibility effects: The p-map and its consequences for constraint organization. Ms., University of California, Los Angeles.

Vanelli, Laura. 1979. L'allungamento delle vocali in friulano. Ce fastu? 55: 66-76.

Vanelli, Laura. 1986. La fonologia dei prestiti in friulano. In Raetia antiqua et moderna, eds. Gunter Holtus and Kurt Ringger, 355-376. Tübingen: Niemeyer.

Vaux, Bert, and Andrew Wolfe. 2009. The appendix. In Contemporary views on architecture and representations in phonology, eds. Eric Raimy and Charles Cairns, 101-144. Cambridge: MIT Press. 
Whalen, Dough H., and Patrice S. Beddor. 1989. Connections between nasality and vowel duration and height: elucidation of the Eastern Algonquian intrusive nasal. Language 65: 457-486.

Youngblood, Jessica L. 2007. Vowel length in standard Italian and northern Italian dialects. MA thesis, University of Texas, Austin.

Zec, Draga. 1995. Sonority constraints on syllable structure. Phonology 12: 85-129.

Zec, Draga. 2003. Prosodic weight. In The syllable in Optimality Theory, eds. Caroline Féry and Ruben van de Vijver, 123-143. Cambridge: Cambridge University Press. 